\title{
Nonlinear modeling of unreinforced masonry structures under seismic actions: validation using a building hit by the 2016 Central Italy earthquake
}

\author{
Chiara Ferrero \\ University of Genoa, Department of Civil, Chemical and Environmental Engineering, 16145 Genoa, Italy \\ chiara.ferrero@edu.unige.it
}

Paulo B. Lourenço

ISISE, Department of Civil Engineering, University of Minbo, Campus de Azurém, 4800-058 Guimarães, Portugal

pbl@civil.uminho.pt, bttp:// orcid.org/0000-0001-8459-0199

Chiara Calderini

University of Genoa, Department of Civil, Chemical and Environmental Engineering, 16145 Genoa, Italy

chiara.calderini@unige.it, http://orcid.org/0000-0002-1525-5095

\begin{abstract}
A prolonged seismic sequence struck the regions of Central Italy between August 2016 and January 2017, causing several fatalities and widespread damage to the built environment. The main objective of this work was to study the structural and seismic behavior of "Pietro Capuzi" school, located in Visso, in the Marche region, which was severely damaged by the 2016-2017 Central Italy Earthquake. A 3D finite element (FE) model of the entire school was prepared, adopting a macro-modeling approach to represent masonry materials. An eigenvalue analysis was initially performed in order to identify the dominant modes of vibration of the structure and to calibrate the numerical model according to the results of the dynamic identification tests. Afterwards, nonlinear static analyses were performed on the calibrated FE model to evaluate the seismic response of the structure. Finally, the numerical results obtained in terms of crack pattern and failure mechanisms were compared with the damage experienced by the building. The numerical model proved to accurately predict the seismic response exhibited by the structure during the past seismic events.
\end{abstract}

KEYWORDS. Unreinforced masonry; FE modeling; Seismic assessment; Nonlinear static analysis.

\section{OPEN ACCESS}

Citation: Ferrero, C., Lourenço, P. B., Calderini. C., Nonlinear modeling of unreinforced masonry structures under seismic actions: validation using a building hit by the 2016 Central Italy earthquake, Frattura ed Integrità Strutturale, 51 (2020) 92-114.

Received: 19.05 .2019

Accepted: 11.10.2019

Published: 01.01 .2020

Copyright: (C) 2020 This is an open access article under the terms of the CC-BY 4.0, which permits unrestricted use, distribution, and reproduction in any medium, provided the original author and source are credited. 


\section{INTRODUCTION}

$\mathrm{R}$ ecent and past earthquakes have shown that unreinforced masonry buildings are prone to damage by seismic actions. The seismic assessment of such structures, especially historical ones, is a very demanding task since their response may be affected by several factors, such as masonry mechanical behavior, complex structural and geometric arrangement, connections between diverse structural components and flexibility of horizontal diaphragms [1]. Nowadays several methods are available in the literature for the structural assessment of existing masonry buildings, from simple analytical methods to more advanced numerical methods such as Finite elements and Discrete elements [2]. Recently, numerical modeling strategies, such as FE modeling, have been used more and more to study the behavior of masonry structures, even very large and complex ones, thanks to the increase of computational resources. However, as described in [3], many uncertainties arise in the definition of a structural model with respect to geometry, material properties, internal morphology and structural arrangements due to the limited knowledge usually available as well as the lack of extensive experimental tests. Consequently, numerical models need to be validated or calibrated based on empirical evidences in order to prove their capability to simulate realistically the structural response of masonry buildings [3]. When modal parameters are known from dynamic identification tests, a process of model updating can be carried out to match the numerical mode shapes and frequencies with the experimental ones. On the other hand, if the building under consideration experienced some damage due to earthquakes, a further and effective validation of the numerical model can be performed by comparing the numerical damage with the cracking pattern observed in the real structure.

This work aimed at assessing the seismic performance of "Pietro Capuzi" school, an unreinforced masonry structure located in the municipality of Visso, in the Marche region, Italy. The school suffered severe and extensive damage due to the 20162017 Central Italy earthquake (also named the Amatrice-Norcia-Visso seismic sequence) and it was demolished in 2018 since a strengthening intervention was considered economically inconvenient. "Pietro Capuzi" school was an excellent case study to investigate the seismic capacity of an existing masonry structure for several reasons. Firstly, the school was part of the public buildings permanently monitored by the Seismic Observatory of Structures (hereafter named OSS). As a result, the entire seismic sequence affecting the school was recorded by the existing system of accelerometers, thus providing valuable information in terms of ground motion and structural seismic performance [4] [5]. Secondly, the inspection and the extensive experimental campaign that were performed in 2010-11 on behalf of the OSS supplied detailed documentation regarding geometry, structural configuration and construction details, and helped with the characterization of material properties [6, 7, 8]. Dynamic identification tests were also carried out in 2010 to identify the dynamic response of the structure [9]. Finally, such documentation, acquired from the OSS [10], was integrated with the information about geometry, structural configuration, past interventions and seismic damage supplied by the Italian Network of University Laboratories in Seismic Engineering (RELUIS) and the University of Genova, in charge of post-earthquake surveys [11]. In addition, the photographic record of the progressive damage experienced by the building during the entire seismic sequence was provided by the Italian Department of Civil Protection [12]. The value of the present paper lies in the use of such detailed data, which are rarely available, for the assessment of the seismic performance of a real building. On one hand, the available information about geometry, construction details and material properties enabled to build an accurate numerical model of the structure, which was adequately calibrated according to the results of past dynamic identification tests. On the other hand, the availability of the ground-motion records at the base of the building allowed to validate the numerical model by comparing the numerical and real damage for the actual seismic input which the structure was subjected to.

The paper is organized as follows. Firstly, a description concerning the building, the damage produced by the AmatriceNorcia-Visso seismic sequence and the permanent monitoring system is provided, derived from the information reported in $[4,5,6,7,8,9,10,11,12]$. Then, the preparation and updating of the numerical FE model is described, with a focus on the definition of the mechanical properties of materials and diaphragms. Finally, nonlinear static analyses are carried out, and the numerical results obtained in terms of damage pattern and failure mechanisms are compared with the performance exhibited by the structure during the Amatrice-Norcia-Visso seismic sequence.

\section{DESCRIPTION OF THE BUILDING}

\section{Overall configuration and use}

$\mathrm{B}$ uilt in the 1930s, "Pietro Capuzi" nursery and primary school (Figure 1) was a stand-alone structure located in the urban area of Visso, in the Marche region. The building had four levels, three of them above ground (raised ground floor, first floor and attic) and a basement partially sub-grade (Figure 2). The three levels above ground had a plan area of approximately $605 \mathrm{~m}^{2}$ each, whereas the basement had a plan area of approximately $120 \mathrm{~m}^{2}$. The basement, raised 
ground floor and first floor had an inter-story height of $3.09 \mathrm{~m}, 4.44 \mathrm{~m}$ and $4.26 \mathrm{~m}$, respectively. The attic had a maximum height of about $3.19 \mathrm{~m}$, resulting in a total height above ground of about $13.50 \mathrm{~m}$ in correspondence of the main façade. The total built volume was estimated at about $4800 \mathrm{~m}^{3}$.

The building did not present any irregularity in elevation in the part above ground. However, it was strongly irregular in plan since it presented a T-shape configuration given by the connection of two orthogonal bodies (hereafter named body $\mathrm{A}$ and body B as shown in Figure 2b). The principal axes of the building are oriented in the directions northwest-southeast and northeast-southwest, which will be henceforth indicated as X and Y directions, respectively, as depicted in Figure 2a. Body A, characterized by a rectangular shape elongated in X direction, hosted most of the classrooms, while the areas used as offices, the canteen and toilets were allocated in body B. A staircase connecting the basement, the raised ground floor and the first floor was located on the east side of body B.

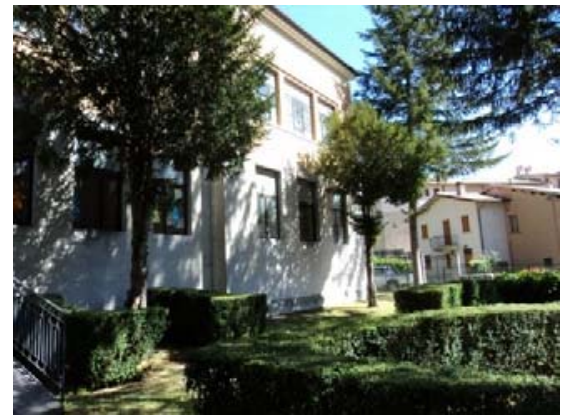

a)

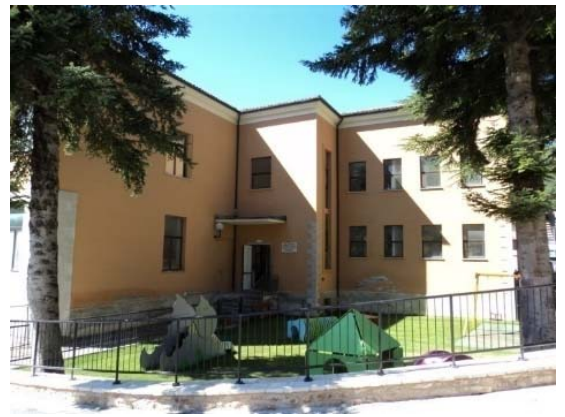

b)

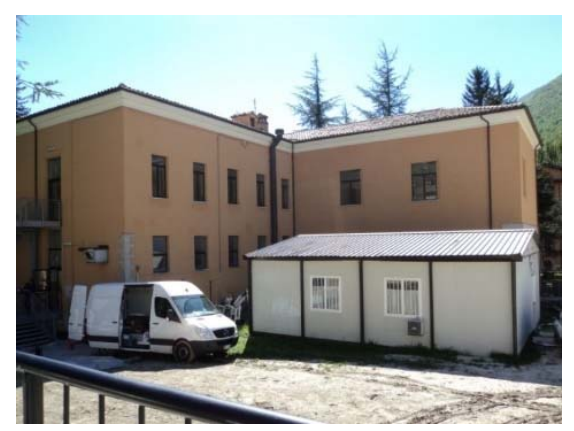

c)

Figure 1: "Pietro Capuzi" school: a) main façade, b) northwest façade, c) northeast façade [6].
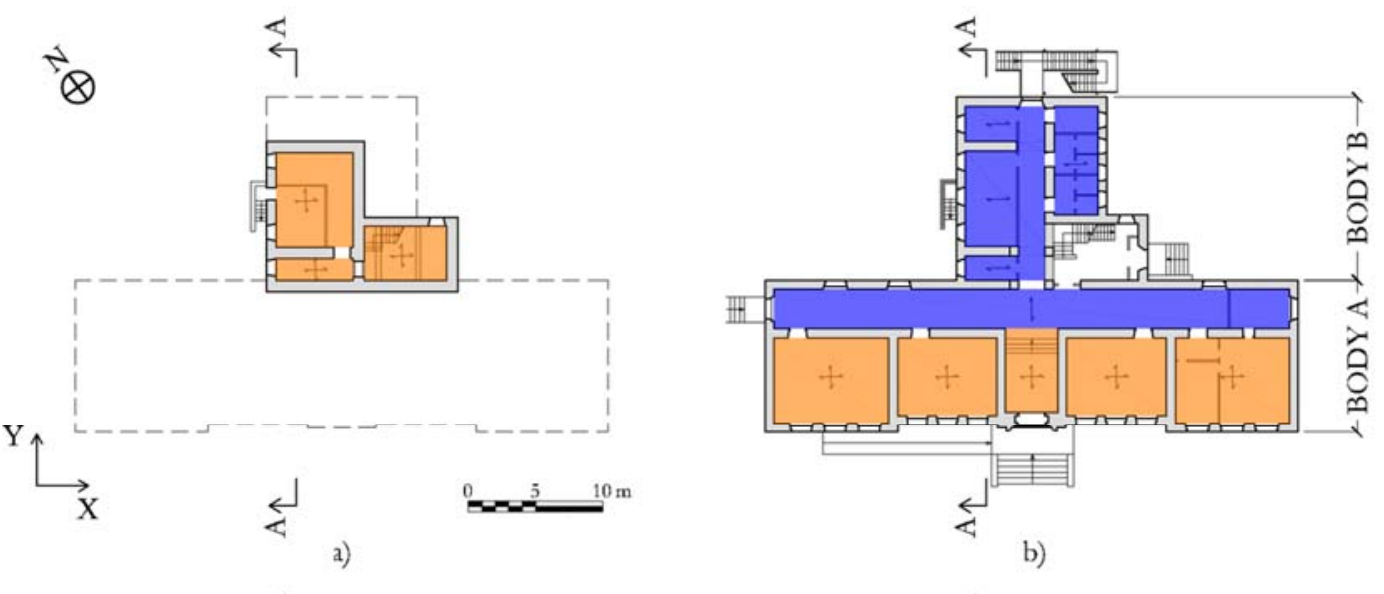

b)

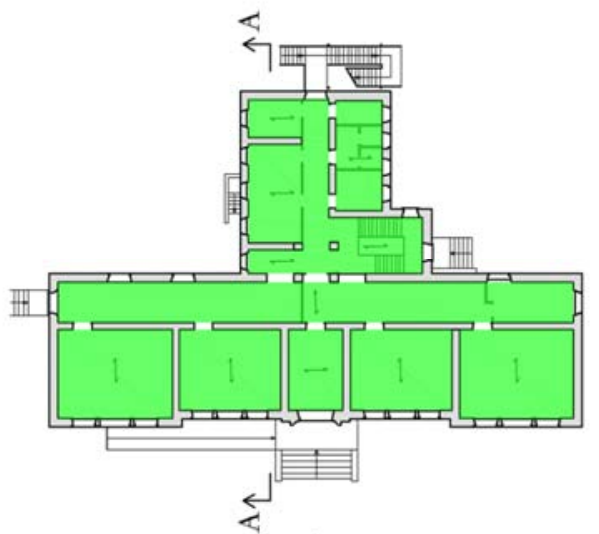

c)

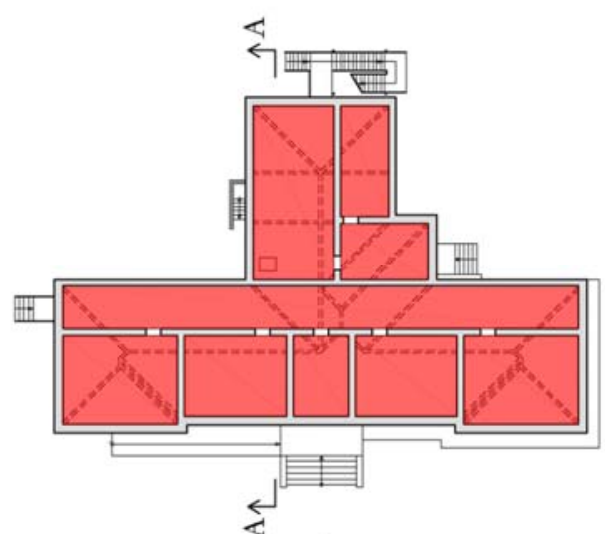

d)

Two-way lightweight concrete slab

One-way lightweight concrete slab

One-way steel-clay slab

Timber roof

Figure 2: Plans of "Pietro Capuzi" school: a) basement, b) raised ground floor, c) first floor, d) attic. 


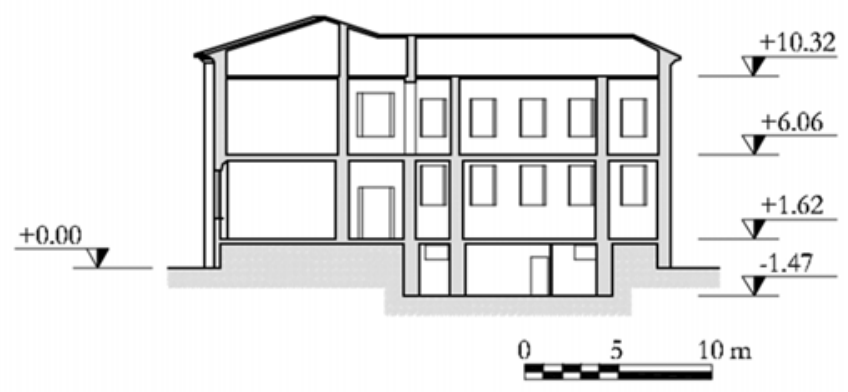

Figure 3: Survey of "Pietro Capuzi" school: section AA (indicated in plan in Figure 2).

\section{Structural configuration and technical details}

The structure of the school consisted of load-bearing masonry walls that were continuous over the full height of the building. In particular, according to the survey available in [6], the perimeter walls raised from the level of the ground (assumed as reference level equal to $+0.00 \mathrm{~m}$ ), while the internal walls of body A, which did not extend downwards into the basement, developed from the height where the slab-on-grade was located (Figure 3). The prevalent type of masonry was stone masonry, whereas the sporadic presence of solid brick masonry was observed in some pillars in the staircase as well as in portions of walls filled with solid bricks during past interventions. The thickness of the walls varied with height, ranging from about $70-85 \mathrm{~cm}$ at the basement to approximately $70 \mathrm{~cm}$ at raised ground floor and $50-70 \mathrm{~cm}$ at first floor. Foundations were made of the same stone masonry of the upper levels that extended downwards until a depth of approximately $60 \mathrm{~cm}$ from the planking level of the basement. Concerning horizontal diaphragms, the slabs of the raised ground floor and first floor were lightweight slabs (one-way or two-ways), with a thickness of $30 \mathrm{~cm}$ each, while the slab between the first floor and attic was a one-way steel-clay slab (hollow clay tiles and steel beams). A concrete bond beam was present at the level of the slab between the raised ground floor and first floor. In the areas of the raised ground floor where there was no basement, the slab-on-grade was made of a reinforced concrete layer placed directly on the ground and covered with terracotta tiles, for a total thickness of $6 \mathrm{~cm}$. The staircase was made of reinforced concrete and was supported by load-bearing masonry walls on three sides, and three masonry pillars on the internal short side. The hipped roof had a timber structure consisting of purlins and rafters that were supported by a system of trusses and by the inner walls extending until the top of the roof. In correspondence of ridges and valleys, hip rafters were present. Above the timber structure, a concrete layer $2 \mathrm{~cm}$ thick and clay tiles were located. A reinforced concrete bond beam was present at the level of the spring line of the roof.

\section{Past damage and previous strengthening interventions}

"Pietro Capuzi" school was damaged by the seismic events that hit the regions of Umbria and Marche between 1997 and 1998. Cracks mainly appeared in the staircase where the two bodies composing the building connected to each other. This led to a strengthening intervention performed in the 1990s, which was aimed at: (1) repairing the seismic damage, (2) improving the seismic capacity of the building, and (3) solving static problems due to the decay of some parts of the timber roof. With respect to the seismic damage, major cracks were repaired using the technique of "cuci and scuci" (a like-for-like repair). Regarding the seismic improvement, the interventions carried out included: (1) addition of metallic profiles studded to the internal side of masonry walls at the level of the slab between the first floor and attic, (2) connection of the roof timber elements to the perimeter walls by means of metallic plates anchored with bars, (3) creation of a steel frame around the openings of the main façade at the first level, (4) addition of metallic tie-rods, (5) injections of lime based mortar in some piers where pipes were filled in the past with solid brick masonry, and (6) filling with solid brick masonry of the spans between the pillars in the staircase. Concerning the decay of the roof, the original timber structure was replaced with new glue laminated timber elements in the central part of body A above the classrooms.

\section{SEISMIC DAMAGE AND MONITORING DATA}

$\mathrm{T}$ he 2016-2017 Amatrice-Norcia-Visso seismic sequence started on August 24 ${ }^{\text {th }}$, 2016 with the Amatrice earthquake $\left(M_{w} 6.0\right)$, which hit a vast area of the Central Apennines producing almost 300 casualties and widespread damage to the built environment. The sequence was characterized by nine mainshocks with moment magnitudes higher than 5, which occurred on August 24th $2016\left(\mathrm{M}_{\mathrm{w}} 6.0\right.$ and $\mathrm{M}_{\mathrm{w}}$ 5.4), October 26 $6^{\text {th }}, 2016\left(\mathrm{M}_{\mathrm{w}} 5.4\right.$ and $\mathrm{M}_{\mathrm{w}}$ 5.9), October $30^{\text {th }}, 2016$ $\left(\mathrm{M}_{\mathrm{w}}\right.$ 6.5) and January $18^{\text {th }}, 2017$ (four shakes with $\left.\mathrm{M}_{\mathrm{w}} \geq 5.0\right)$. 
Damage suffered in the 2016-2017 Amatrice-Norcia-Visso seismic sequence

The most significant damage observed in "Pietro Capuzi" school after the Amatrice-Norcia-Visso seismic sequence is presented in Figure 4, updated on December $8^{\text {th }}, 2016$. A more detailed description can be found in [11]. As shown in Figure $4 \mathrm{a}$, the walls were affected by severe cracks at both the raised ground floor and first floor, especially in the Y direction where the damage was more severe and widespread than in the $\mathrm{X}$ direction. The building mainly presented diagonal shear cracks developing through the entire thickness of the walls in both piers and spandrels. Furthermore, a shear-sliding mechanism producing an important residual deformation was activated in the northwest side of the building (Figure 4b). Flexural cracks were also observed on the southeast side of body B (Figure 4c). In addition to the in-plane damage, an out-of-plane mechanism occurred in the northwest corner of the building, resulting in the partial collapse of masonry walls (Figure 4d). With regard to the slabs, two local collapses occurred between the raised ground floor and first floor (Figure 4e). Furthermore, the steel slab between the first floor and attic experienced an extensive collapse because of the out-of-plane mechanisms as well as cracks along the metallic profiles in the portions of slab still standing. As for the connection between vertical walls and slabs, horizontal cracks were present in the external walls at the slab locations. In the interior, severe cracks were observed in correspondence of the connection between walls and slabs (Figure 4f).

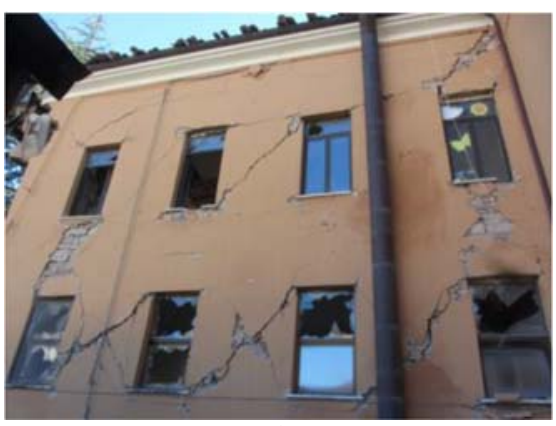

a)

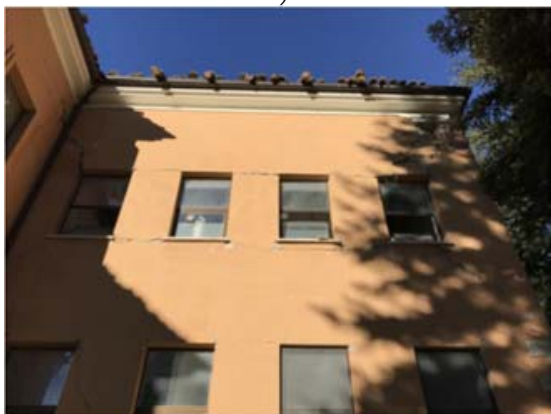

c)

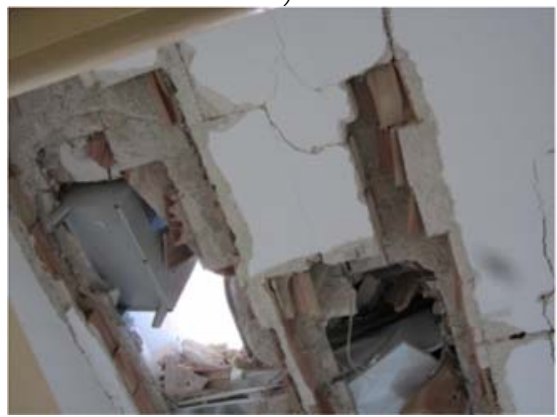

e)

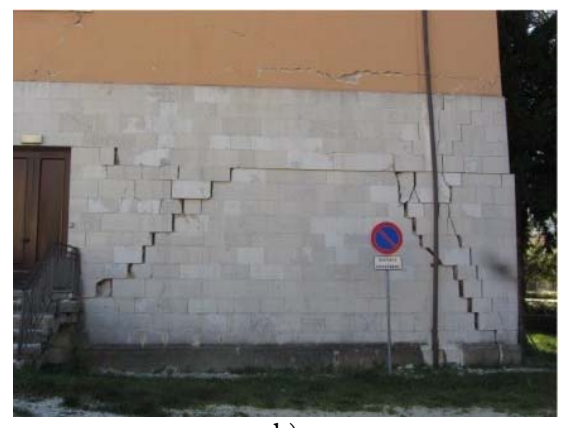

b)

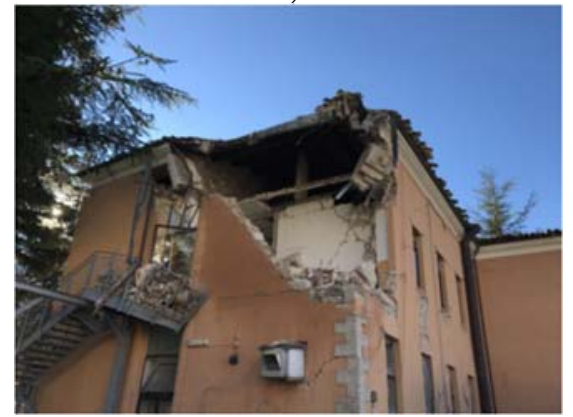

d)

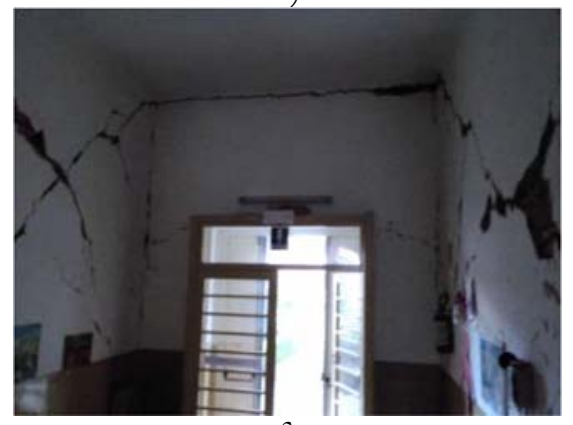

f)

Figure 4: Damage state updated on December $8^{\text {th }}, 2016$ : a) diagonal shear cracks in piers and spandrels, b) shear-sliding mechanism, c) flexural cracks, d) out-of-plane mechanism, e) local collapse of the slab between the raised ground floor and first floor, f) cracks in correspondence of the connection between walls and slabs [11].

A partial reconstruction of the damage development was carried out thanks to the photographic documentation provided in $[11,12]$. As shown in Figure 5a, the seismic event of August 24th induced an in-plane response with slight to moderate cracking affecting the walls. Severe cracks were also observed in few piers of the external and internal walls. Figure $5 \mathrm{~b}$ shows 
the significant deterioration of the building conditions produced by the earthquakes of October $26^{\text {th }}$, 2016. Large and extensive cracks occurred in most of the walls, especially in the Y direction. Furthermore, an out-of-plane mechanism was activated in one corner. As shown in Figure 5c, the damage state did not change significantly after the shake of October $30^{\text {th }}$ as compared with October $26^{\text {th }}$.

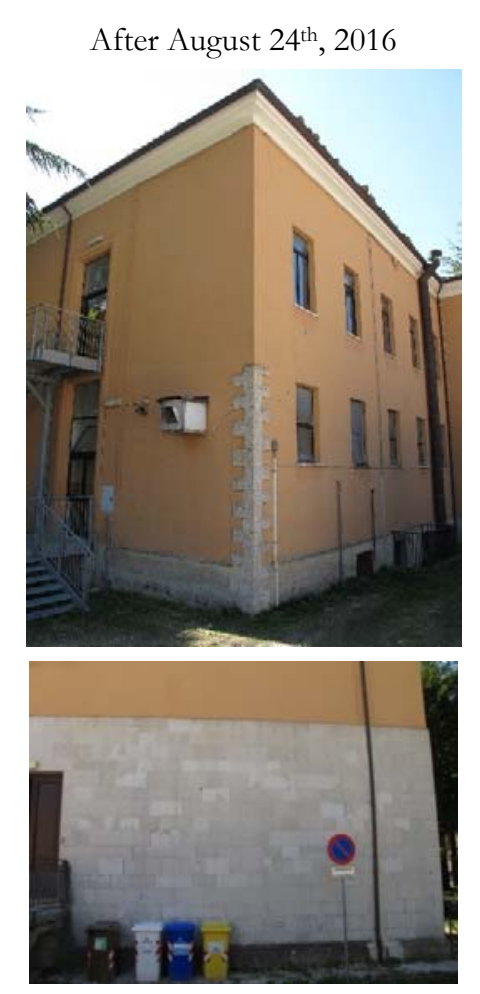

a)
After October 26, 2016
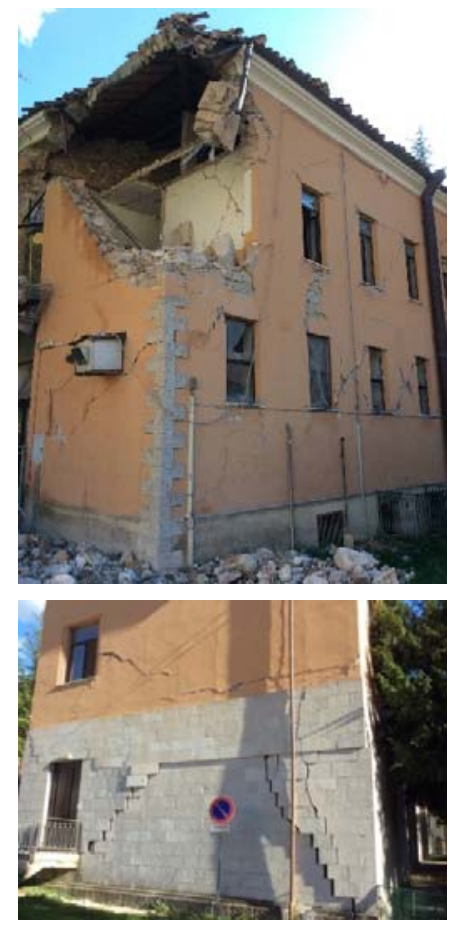

b)
After October 30"th 2016
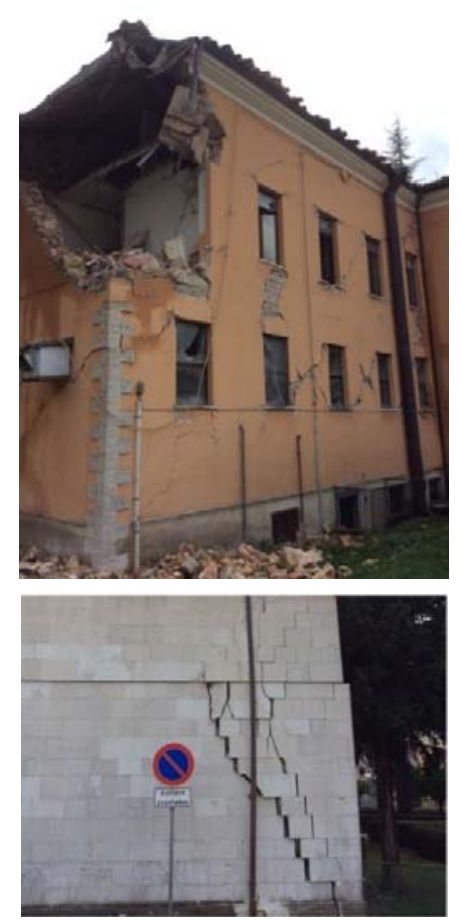

c)

Figure 5: Damage observed in "Pietro Capuzi" school after the earthquakes that occurred on: a) August 24"h, 2016, b) October 26"th, 2016, and c) October 30th $2016[11,12]$.

\section{Permanent Monitoring by the Seismic Observatory of Structures}

As part of the OSS, "Pietro Capuzi" school was permanently monitored by a system of accelerometers located in different parts of the building (Figure 6): one tri-axial accelerometer was located in the basement to measure the seismic input, and ten bi-axial accelerometers were placed at the first and second levels, at the intrados of the slabs, to record the accelerations experienced by the structure.

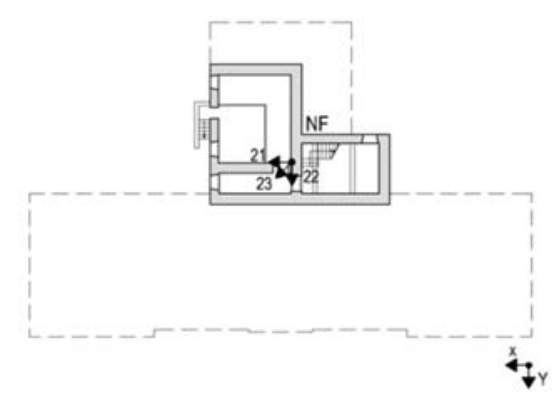

a)

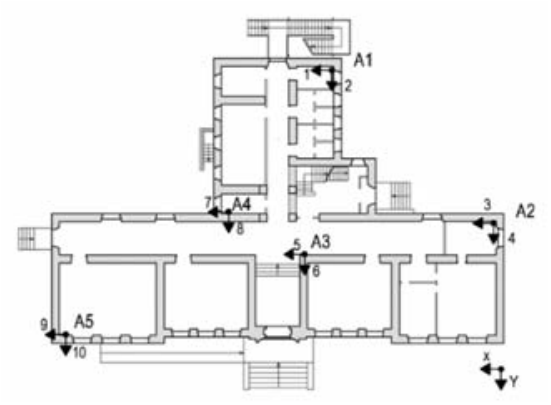

b)

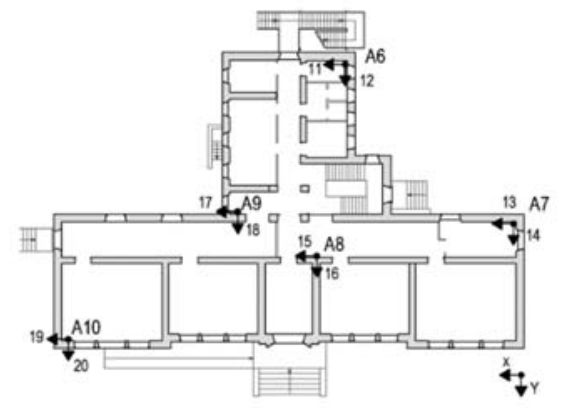

c)

Figure 6: Location of the accelerometers: a) basement, b) raised ground floor, c) first floor [10].

This monitoring system was used to identify the dynamic behavior of "Pietro Capuzi" school within the framework of the experimental campaign performed in 2010-2011 on behalf of the OSS. As described in [9], dynamic identification tests were carried out by CESI S.p.A to determine the natural frequencies and mode shapes of the first three modes of vibration of 
the structure. However, since no visualization of the mode shapes was provided in [9], the authors obtained a graphical representation of the deformed shape drawing on scale in the plan of the building the modal displacements associated to each mode shape vector, as shown in Figure 7. It is observed that the three modes identified experimentally are global modes. In particular, the first mode $(3.18 \mathrm{~Hz})$ and the third mode $(4.05 \mathrm{~Hz})$ correspond to translational modes in the $\mathrm{Y}$ and $\mathrm{X}$ directions of the building, respectively, while the second mode $(3.76 \mathrm{~Hz})$ is a torsional mode. Note that in order to gather more information about the modal response of the structure and visualize animations of the mode shapes, a further dynamic identification, described in [13], was performed by the authors processing the signals recorded during the dynamic tests carried out in 2010 by means of ARTeMIS Modal 5.0 software [14]. Though richer in terms of more possible frequencies, this modal identification was in accordance with the one performed by CESI S.p.A [9].
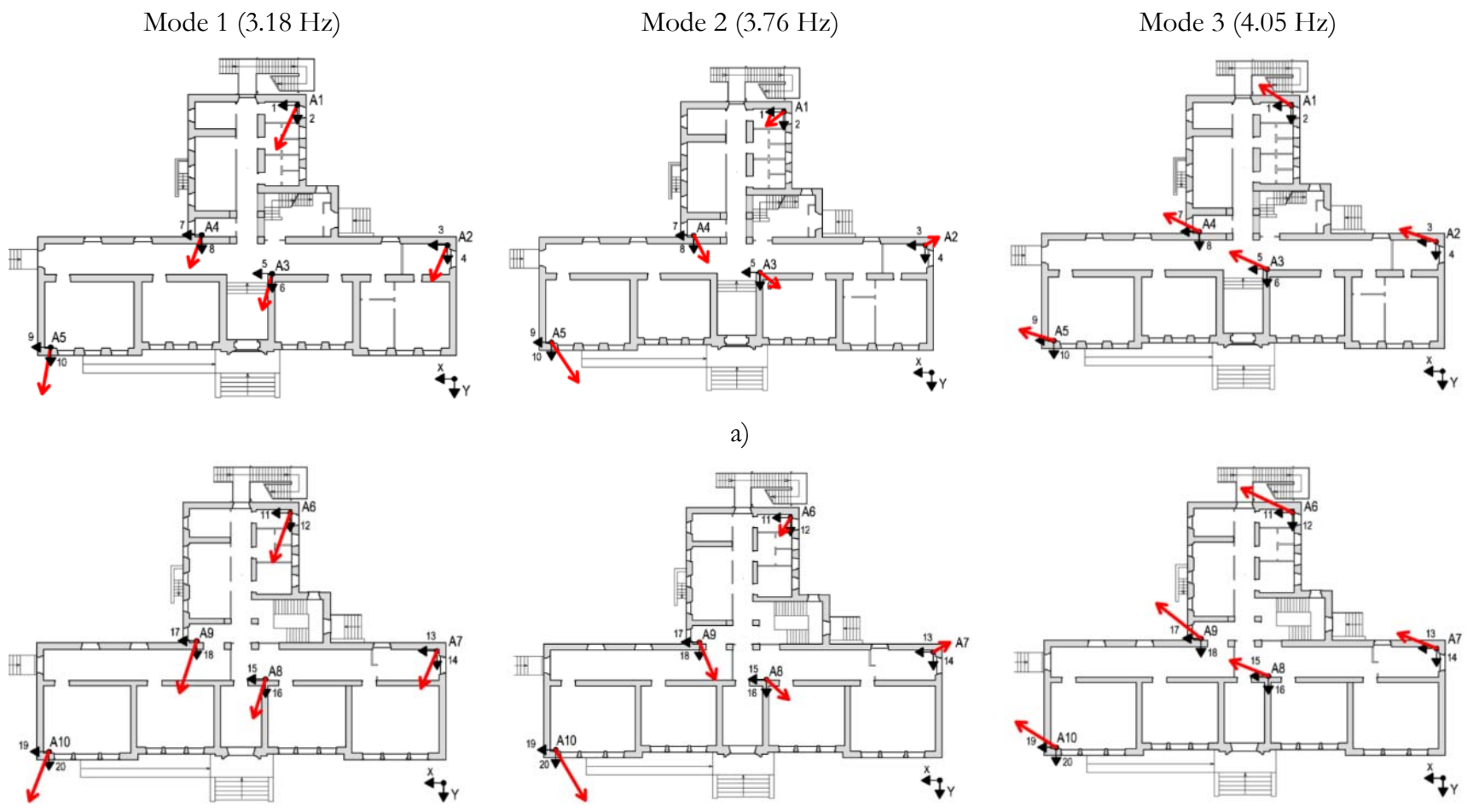

b)

Figure 7: Mode shapes of the first three modes obtained from dynamic identification tests: a) raised ground floor, b) first floor.

For the purpose of this work, the OSS provided the authors with the time histories in acceleration and displacement (double integrated from acceleration) relative to each accelerometer composing the monitoring system for the seismic events that occurred on August 24th $\left(M_{w} 6.0\right)$, October $26^{\text {th }}\left(M_{w} 5.4\right.$ and 5.9) and October 30th $\left(M_{w} 6.5\right)[4,5,11]$. These recordings allowed the characterization of the seismic input at the base of the structure and aided in drawing conclusions about the accelerations experienced by the building during the entire seismic sequence. The seismic parameters obtained processing the time histories provided by the OSS are gathered in Table 1, where: PGA is the peak ground acceleration, PSA is the maximum acceleration recorded in the structure, $\alpha_{\mathrm{PSA} / \mathrm{PGA}}$ is the amplification factor calculated as the ratio between PSA and PGA, Dmax is the maximum inter-story drift i.e. the maximum ratio of the relative floor displacement to the height of the corresponding floor.

Regarding the seismic input, which was measured in the two horizontal directions $\mathrm{X}$ and $\mathrm{Y}$ by means of the tri-axial accelerometer located at the base of the building, it is observed that the structure was subjected to significant values of horizontal ground motion (Table 1). The highest values of horizontal PGA were produced by the $\mathrm{M}_{\mathrm{w}} 5.9$ earthquake of October $26^{\text {th }}$, which caused the most severe damage to the structure. It is noted that a higher value of PGA was registered in the $\mathrm{Y}$ direction $(0.47 \mathrm{~g})$ when compared to the X direction $(0.36 \mathrm{~g})$.

With respect to the seismic performance exhibited by "Pietro Capuzi" school during the entire seismic sequence, firstly it is to note that the structure underwent values of acceleration that were significantly amplified compared to the maximum acceleration measured at the base. Indeed, very high values of amplification factors, even higher than 4, were obtained. Furthermore, some interesting observations could be drawn analyzing the values of inter-story drift produced during the 
seismic sequence. Note that the OSS provides the following reference values regarding drift-damage relation for masonry buildings: (1) no damage for drift ranging from 0 to $2 \%$, (2) slight damage for drift ranging from $2 \%$ to $4.5 \%$, (3) moderate damage for drift ranging from $4.5 \%$ to $8 \%$, and (4) severe damage for drift higher than $8 \%$ [15]. The highest values of drift were produced by the $\mathrm{M}_{\mathrm{w}} 5.9$ earthquake of October $26^{\text {th }}$, for which values of $13.53 \%$ and $16.01 \%$ were obtained in the $\mathrm{X}$ and $\mathrm{Y}$ directions, respectively. These values are significantly higher than the ones resulting from the shakes of August $24^{\text {th }}$ and October 26 ${ }^{\text {th }}\left(M_{w}\right.$ 5.4). According to the reference values provided by the OSS, the values of drift obtained for the $M_{w}$ 5.9 earthquake of October $26^{\text {th }}$ correspond to severe damage, while moderate and slight damage are respectively associated to the shakes of August 24th and October 26 th $\left(\mathrm{M}_{\mathrm{w}} 5.4\right)$. Note that the values of drift obtained for the $\mathrm{M}_{\mathrm{w}} 6.5$ earthquake of October $30^{\text {th }}$ are less meaningful since the building was severely damaged by the previous seismic events. These results are consistent with the level of damage developed by the building (see previous section). Furthermore, the higher values of drift obtained in the $\mathrm{Y}$ direction for the seismic events of October agree with the more severe damage observed in the structure in the $\mathrm{Y}$ direction in comparison with the $\mathrm{X}$ direction. Consequently, the inter-story drift was found to represent a reliable measure of the seismic damage suffered by the structure.

\begin{tabular}{|c|c|c|c|c|c|c|c|c|}
\hline Seismic event & PGA x $[\mathrm{g}]$ & PGA y $[\mathrm{g}]$ & PSA x $[g]$ & PSA y $[g]$ & $\alpha_{\mathrm{PSA} / \mathrm{PGA}, \mathrm{x}}$ & $\alpha_{\mathrm{PSA} / \mathrm{PGA}, \mathrm{y}}$ & $\begin{array}{c}\operatorname{Dmax} x \\
{[\% 0]}\end{array}$ & $\begin{array}{c}\text { Dmax y } \\
{[\% 0]}\end{array}$ \\
\hline $2016 / 08 / 24{ }_{2} \mathrm{M}_{\mathrm{w}}=6.0$ & 0.33 & 0.32 & 1.05 & 0.80 & 3.21 & 2.52 & 6.10 & 4.23 \\
\hline $2016 / 10 / 26 \_M_{w}=5.4$ & 0.30 & 0.21 & 1.27 & 0.78 & 4.27 & 3.70 & 3.95 & 2.46 \\
\hline $2016 / 10 / 26 \_M_{w}=5.9$ & 0.36 & 0.47 & 1.41 & 1.33 & 3.86 & 2.81 & 13.53 & 16.01 \\
\hline $2016 / 10 / 30 \_\mathrm{M}_{\mathrm{w}}=6.5$ & 0.29 & 0.30 & 1.36 & 1.47 & 4.65 & 4.89 & 5.52 & 10.98 \\
\hline
\end{tabular}

Table 1: Ground motion and structural seismic response for the earthquakes that occurred on August $24^{\text {th }}$, October $26^{\text {th }}$ and October $30^{\text {th }}$.

A further characterization of the seismic input was performed in terms of frequency. SeismoSignal 2016 [16] was used to obtain the acceleration response spectra of the acceleration records provided by the OSS. Figure 8 shows a comparison between the 5\% damped acceleration response spectra of the horizontal components of motion in the $\mathrm{X}$ and $\mathrm{Y}$ directions for the four earthquakes considered and the elastic response spectrum in accordance with the Italian Building Code [17] (hereafter called NTC2008) for a return period of 712 years and soil of type B, as identified in [7]. It is observed that the seismic events of August $24^{\text {th }}\left(M_{w} 6.0\right)$ and October $26^{\text {th }}\left(M_{w} 5.9\right)$, which caused the most important damage to the structure, result in significantly larger accelerations compared to the ones of the elastic spectrum of NTC2008. It is also noted that the Y component of the acceleration spectrum of the October $26^{\text {th }}$ earthquake exceeds the code spectrum for all the significant ranges of period, thus agreeing with the severe damage suffered by the structure in this direction.

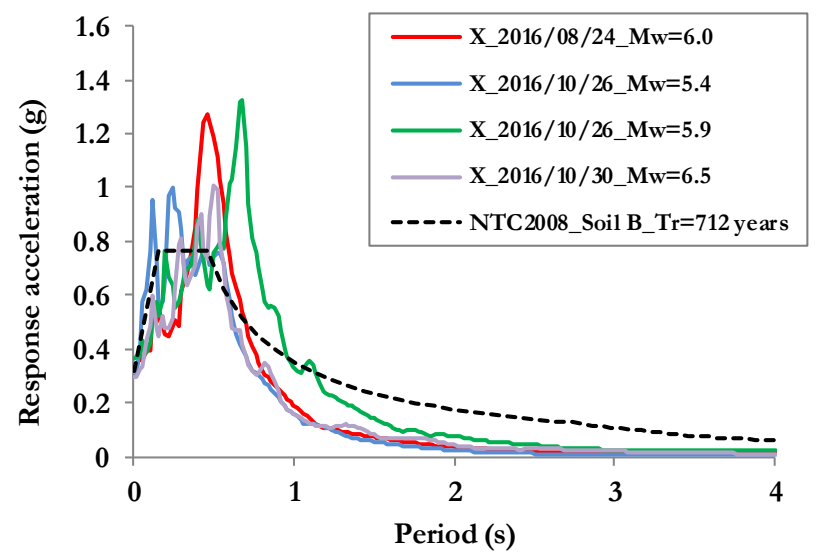

a)

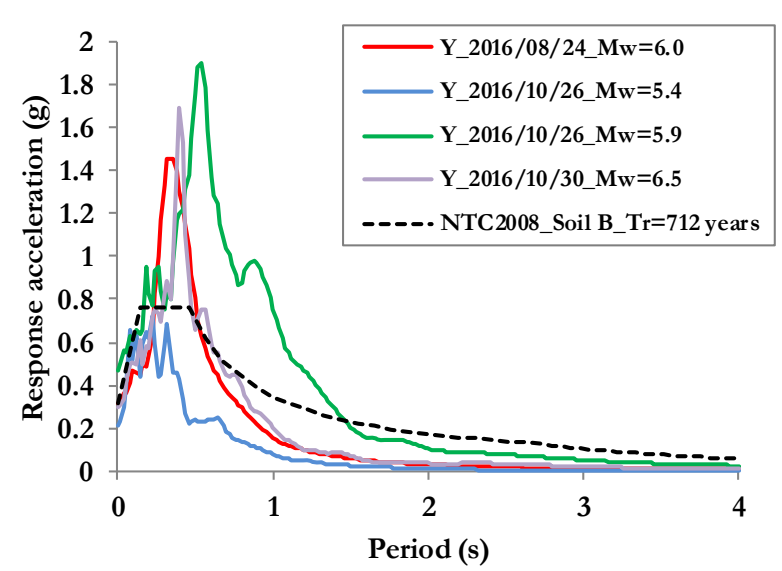

b)

Figure 8: Comparison between the response spectra of the seismic events of August $24^{\text {th }}$, October $26^{\text {th }}$ and October $30^{\text {th }}$ and the elastic spectrum of NTC2008 for soil B and return period Tr=712 years (damping 5\%): a) X component, b) Y component. 


\section{NUMERICAL MODEL}

\section{Preparation of the FE model}

3D finite element (FE) model of "Pietro Capuzi" school was created in Midas FX+ Version 3.3.0 Customized A Pre/Post-processor for DIANA software $[18,19]$. A macro-modeling approach was used to represent masonry, 11 which was considered as a homogeneous material. The definition of the geometry, based on the survey provided in [6], required some modeling choices by the authors. The first decision to be made was the modeling strategy of the basement, which was partially sub-grade (see Figure 3). Since modeling building portions below ground is often controversial, especially when detailed information about foundations and soil is not available, three different models were created, as depicted in Figure 9. Model A neglects the portion of the basement underground, whereas model B and C take it into consideration by extending the walls of the basement downwards. The main distinction between models $\mathrm{B}$ and $\mathrm{C}$ is that the first one considers only the walls where the basement was located according to the architectural drawings [6], whereas the second one assumes an equal height underground along all the walls of body B, in agreement with past modeling strategies [8]. Note that the passive earth pressure exerted on the walls of the basement was not considered due to the limited height of the portion of masonry underground. The choice of the model to use for structural analyses was based on the comparison between the experimental and numerical responses of the different models in terms of natural frequencies and mode shapes (see the following section).

The second modeling choice dealt with the base level to adopt for perimeter and internal walls. As described above, walls raised from diverse heights with reference to the ground in different parts of the building (see Figure 3). This difference was included in the models, as illustrated in Figure 9. In particular, it can be observed that the base level of the internal walls of body A is located at the height of $1.47 \mathrm{~m}$ with reference to the ground level $(+0.00 \mathrm{~m})$, while the internal walls of body B (where there is no basement underground) and the perimeter walls develop from the ground level.

Finally, since the slabs were modeled without an explicit inclusion of the thickness, they were located at half the height of their actual thickness (mid-plane). The slab between the raised ground floor and first floor was located at the height of 5.91 $\mathrm{m}$ (with reference to the ground level), while the slab between the first floor and attic was situated at the height of $10.25 \mathrm{~m}$. As for models B and C, the slabs between the basement and raised ground floor were located at the height of $1.47 \mathrm{~m}$.
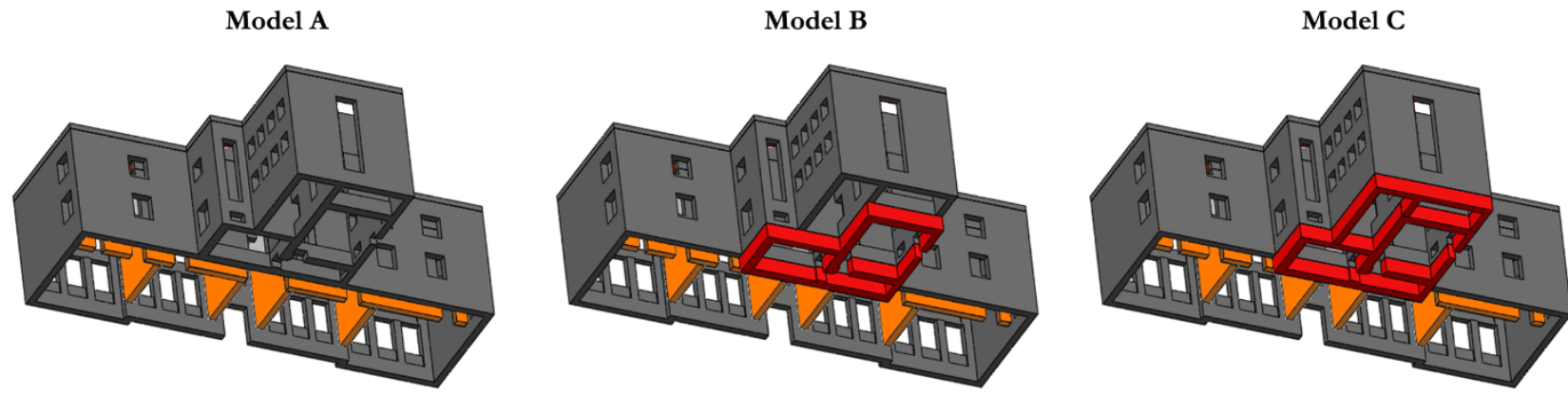

Basement underground $-1.47 \mathrm{~m}$

Base level $+0.00 \mathrm{~m}$

Base level $+1.47 \mathrm{~m}$

Figure 9: Geometry definition: different FE models prepared for the school and different base levels.

Masonry walls were modeled using solid FEs; in particular, four-node three-sided isoparametric solid tetrahedron elements (TE12L) were adopted [19]. Although the use of shell elements for the walls would have resulted in a significant reduction of the number of degrees of freedom and, consequently, in a more limited computational effort, the strategy of using solid FEs was adopted because of the presence of masonry panels characterized by a similar length in both axial and transversal directions. Regarding diaphragms, three-node triangular (T15SH) and four-node quadrilateral (Q20SH) isoparametric shell elements were used to model the intermediate slabs [19]. The roof was built as an ensemble of inclined surfaces supported by masonry walls, as shown in Figure 10a. Since a detailed survey of the roof timber structure was not available, it was believed that this solution might allow an adequate load distribution on the perimeter walls. As regards the roof, only threenode triangular isoparametric shell elements were adopted to assure a better-quality mesh and prevent the creation of elements with undesirable shapes in the corners. Finally, 1D elements were used to model reinforced concrete beams and tie-rods. In particular, two-node, three-dimensional beam elements (L12BE [19]) were adopted for the reinforced concrete beams located at the entrance and in the staircase as well as the reinforced concrete bond beam present at the top of the 
building. Two-node regular directly integrated (1-point) truss elements (L2TRU) were used to mesh metallic tie-rods [19]. Regarding the boundary conditions, the soil was considered infinitely stiff, consequently all the degrees of freedom were restrained at the base of the walls.

The geometry of the three-dimensional model of the school is shown in Figure 10 for model B. In total, the numerical model is composed by 180.567 nodes and 696.997 elements in the case of model A, 187.988 nodes and 727.853 elements as for model B, and 189.256 nodes and 730.953 elements in the case of model C.

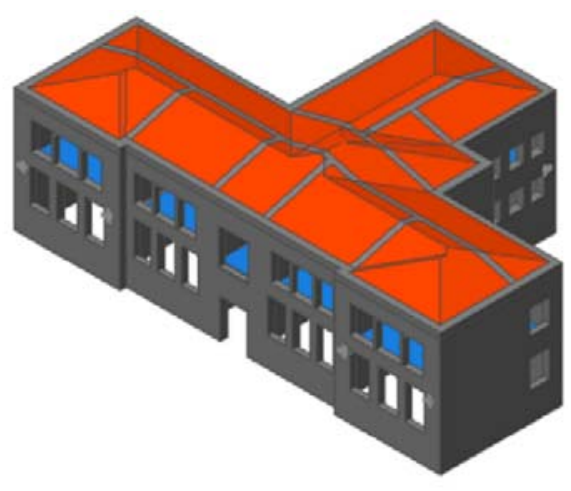

a)

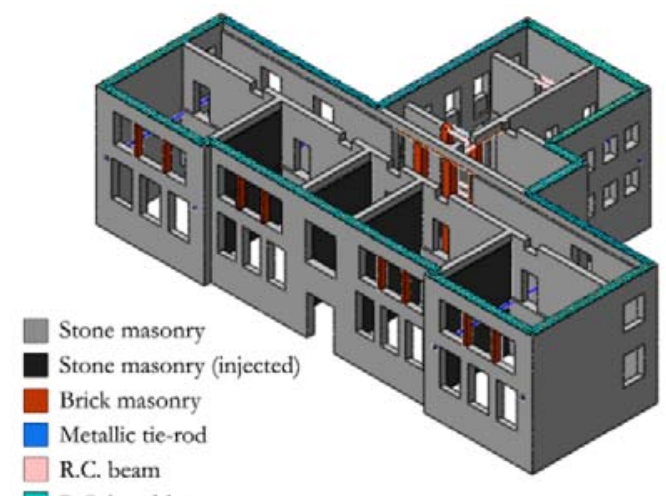

b)

Figure 10: Three-dimensional model: a) geometry, b) description of the materials (slabs and roof are not represented).

\section{Material and diaphragm properties}

Material nonlinearity was assumed only for masonry, whereas linear elastic behavior was adopted for slabs, reinforced concrete beams and tie-rods. The nonlinear behavior of masonry was simulated in the numerical model by means of the Total Strain Rotating Crack model available in DIANA [19]. As shown in Figure 11, an exponential stress-strain relationship was adopted to represent the behavior in tension, while a parabolic stress-strain relationship was assumed for compression.

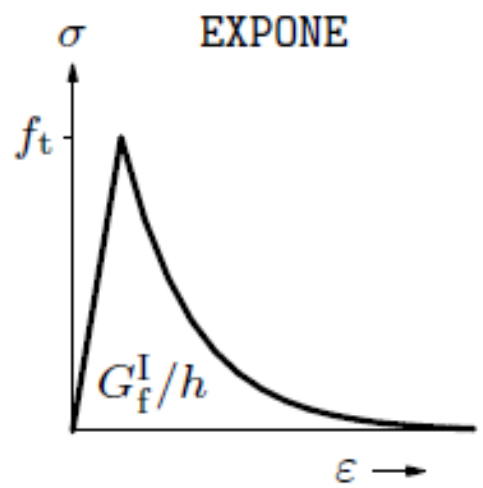

a)

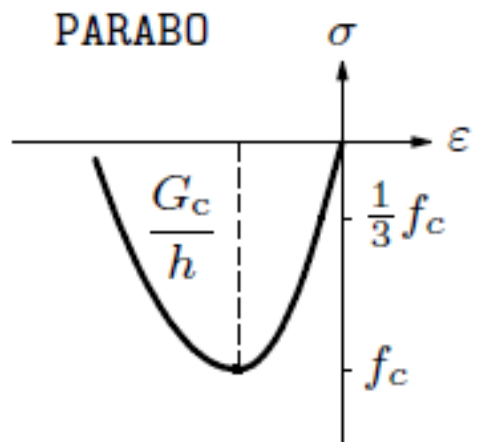

b)

Figure 11: Nonlinear behavior of masonry: a) exponential softening in tension, b) parabolic hardening-softening in compression [19].

Three different types of masonry were identified in the building and represented in the FE model (Figure 10): (1) cut stone masonry with good texture, (2) stone masonry injected during past interventions, and (3) solid brick masonry. The physical and mechanical properties adopted in the numerical model for these types of masonry are reported in Table 2. Since a complete mechanical characterization of these materials was not available, their mechanical properties were derived from the Italian Building Code (NTC2008) [17] and its explanatory note (Circolare n.617 of 2009, hereafter named Circolare [20]) as wells as recommendations from literature, considering also the results of past inspections and tests [7,11]. The values of the elasticity modulus and compressive strength were estimated according to the recommendations given by the Italian Circolare for an adequate knowledge level (LC2) [20]. The latter was adopted on the basis of the knowledge level obtained from past inspections and experimental tests regarding geometry, constructions details and materials [20]. Consequently, the elasticity modulus and compressive strength were assumed equal to the average of the range of values proposed by the Italian Circolare for the different types of masonry present in the building [20]. As prescribed for an adequate knowledge level [20], a confidence factor equal to 1.2 was adopted to reduce the compressive strength. Corrective coefficients were 
applied to improve material properties due to the presence of injections and good mortar. In particular, the coefficient related to injections (equal to 1.5 [20]) was used for stone masonry panels retrofitted during past interventions, while the coefficient related to good quality mortar (equal to 1.5 [20]) was adopted for brick masonry. The values of the tensile strength were estimated from the shear strength proposed by the Italian Circolare [20] using the relations and recommendations provided in $[21,22]$. The values of fracture energies were determined based on information available in literature [22, 23].

\begin{tabular}{cccc}
\hline Material property & $\begin{array}{c}\text { Stone } \\
\text { masonry }\end{array}$ & $\begin{array}{c}\text { Stone masonry } \\
\text { (+ injections) }\end{array}$ & $\begin{array}{c}\text { Brick masonry } \\
\text { (+ good mortar) }\end{array}$ \\
Specific weight $\left[\mathrm{kN} / \mathrm{m}^{3}\right]$ & 21 & 21 & 18 \\
Elasticity modulus $[\mathrm{MPa}]$ & 1740 & 2610 & 2250 \\
Poisson's ratio $[-]$ & 0.2 & 0.2 & 0.2 \\
Compressive strength $[\mathrm{MPa}]$ & 2.67 & 4.00 & 4.00 \\
Compressive fracture energy $[\mathrm{N} / \mathrm{mm}]$ & 4.27 & 6.40 & 6.40 \\
Tensile strength $[\mathrm{MPa}]$ & 0.108 & 0.163 & 0.190 \\
Tensile fracture energy $[\mathrm{N} / \mathrm{mm}]$ & 0.024 & 0.024 & 0.024 \\
\hline
\end{tabular}

Table 2: Material properties of the different types of masonry considered in the numerical model.

The physical and mechanical properties adopted for reinforced concrete (beams) and steel (tie-rods) are reported in Table 3. Since no mechanical characterization was available for these materials, such properties were derived from NTC2008 [17].

\begin{tabular}{ccc}
\hline Material property & Concrete & Steel \\
Specific weight $\left[\mathrm{kN} / \mathrm{m}^{3}\right]$ & 25 & 78.5 \\
Modulus of elasticity [MPa] & 31500 & 210000 \\
Poisson's ratio [-] & 0.2 & 0.29 \\
\hline
\end{tabular}

Table 3: Material properties of reinforced concrete and steel.

Regarding the diaphragms, their bending and axial stiffness were computed by DIANA software [19] considering the elasticity modulus of the material assigned to the slabs and the thickness of the FEs adopted to model them. In this work, an equivalent modulus of elasticity $(E)$ and an equivalent thickness $(b)$ were calculated based on the real bending and axial stiffness of a strip of slab as wide as the spacing between the principal elements composing slab structure. An isotropic and orthotropic material was employed for two-way and one-way slabs, respectively. For two-way slabs, the same stiffness was adopted in all directions. Contrarily, for one-way slabs the stiffness in the secondary direction was assumed as the $10 \%$ of the one adopted in the principal direction, based on a sensitivity analysis on the global modal response. The stiffness in the orthogonal vertical direction was estimated in accordance with the requirements of orthotropic elasticity reported in [19]. Table 4 presents the in-plane axial stiffness in the principal and secondary directions $\left(E_{1} h\right.$ and $\left.E_{2} h\right)$ and the bending stiffness in the vertical direction $\left(E_{3} h^{3} / 12\right)$ for the different types of slab present in the building.

\begin{tabular}{ccccc}
\hline Type of diaphragm & $\begin{array}{c}\text { Type of } \\
\text { material }\end{array}$ & $\begin{array}{c}E_{1} h \\
(\mathrm{kN} / \mathrm{m})\end{array}$ & $\begin{array}{c}E_{2} h \\
(\mathrm{kN} / \mathrm{m})\end{array}$ & $\begin{array}{c}E_{3} h^{3} / 12 \\
(\mathrm{kNm})\end{array}$ \\
$\begin{array}{c}\text { Lightweight concrete slab (one-way) } \\
\text { orthotropic }\end{array}$ & $3.00 \mathrm{E}+06$ & $3.00 \mathrm{E}+05$ & $7.05 \mathrm{E}+03$ \\
Lightweight concrete slab (two-way) & isotropic & $2.64 \mathrm{E}+06$ & $2.64 \mathrm{E}+06$ & $1.06 \mathrm{E}+04$ \\
Steel slab (one-way) & orthotropic & $3.82 \mathrm{E}+05$ & $3.82 \mathrm{E}+04$ & $6.62 \mathrm{E}+02$ \\
Roof & isotropic & $1.89 \mathrm{E}+06$ & $1.89 \mathrm{E}+06$ & $5.67 \mathrm{E}+02$ \\
\hline
\end{tabular}

Table 4: Properties adopted for the diaphragms in the numerical model. 


\section{Eigenvalue analysis and model updating}

A first eigenvalue analysis was carried out to obtain the natural frequencies and modes shapes of the three different models prepared for "Pietro Capuzi" school. The results obtained in terms of the first three global frequencies are similar for the three models. In particular, the first three frequencies range from $5.63 \mathrm{~Hz}$ to $6.00 \mathrm{~Hz}$ for model A, from $5.57 \mathrm{~Hz}$ to 5.92 $\mathrm{Hz}$ for model $\mathrm{B}$ and from $5.51 \mathrm{~Hz}$ to $5.80 \mathrm{~Hz}$ for model C. Figure 12 shows the mode shapes for the first three global modes identified for model A, B and C. For all the models, the first mode corresponds to a translational mode in the $\mathrm{Y}$ direction of the building, while the second mode is a torsional mode. With respect to the third mode, it is characterized by a translational movement of body $\mathrm{B}$ in the $\mathrm{X}$ direction for models $\mathrm{A}$ and $\mathrm{B}$, while it is associated to a torsional movement of body A for model C.

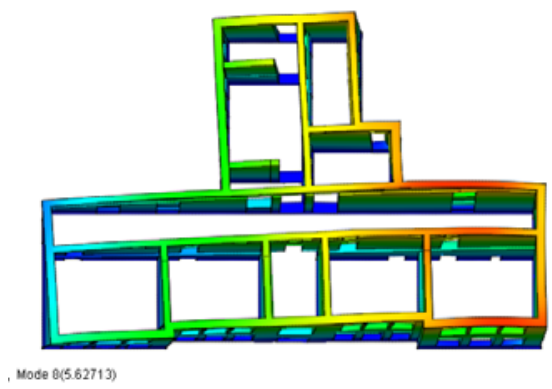

Mode $1(5.63 \mathrm{~Hz})$

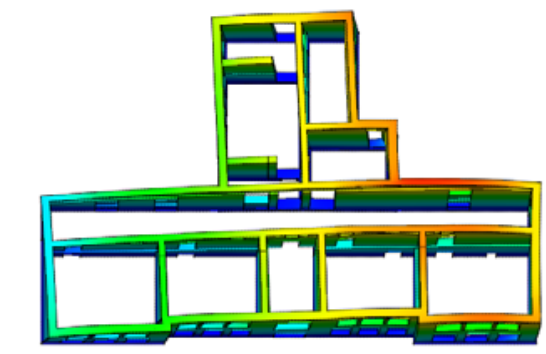

Mode $1(5.57 \mathrm{~Hz})$

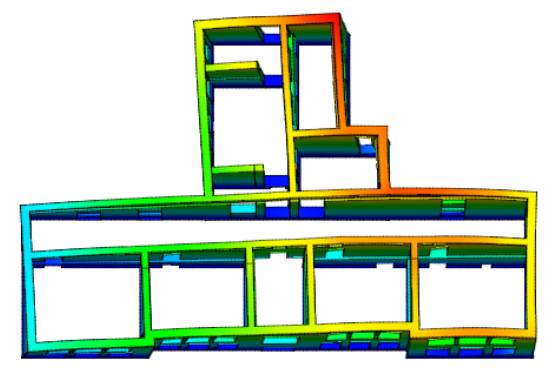

Mode 8(5.51155)

Mode $1(5.51 \mathrm{~Hz})$

Model A

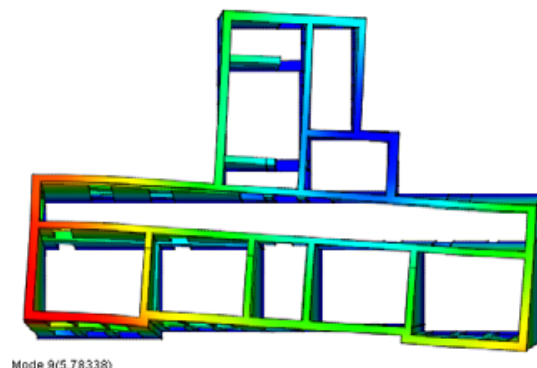

Mode $2(5.78 \mathrm{~Hz})$

Model B

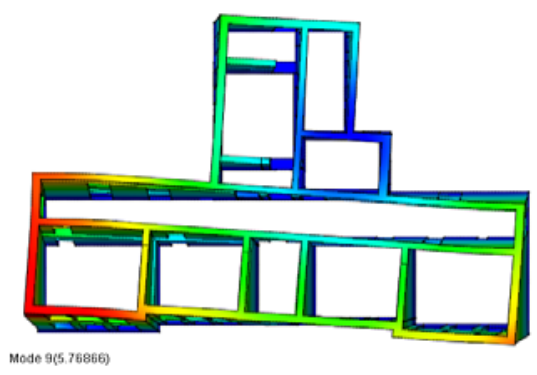

Mode $2(5.77 \mathrm{~Hz})$

Model C

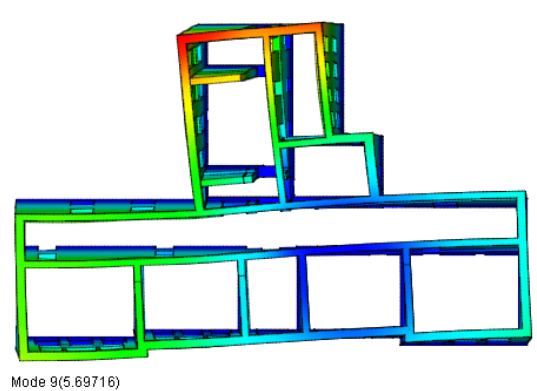

Mode $2(5.70 \mathrm{~Hz})$

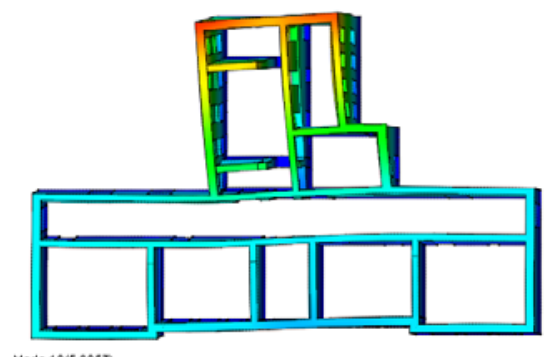

Mode $3(6.00 \mathrm{~Hz})$

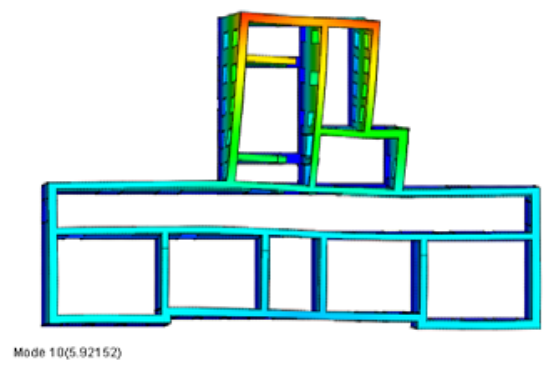

Mode $3(5.92 \mathrm{~Hz})$

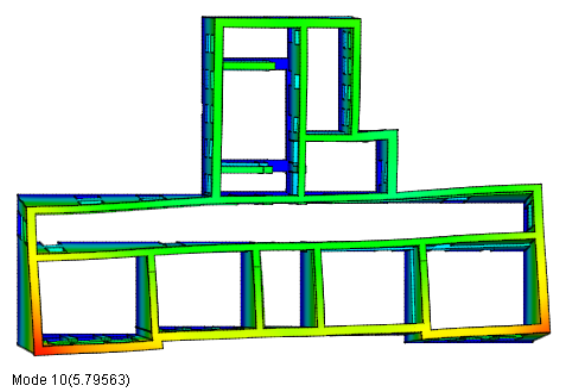

Mode $3(5.80 \mathrm{~Hz})$

Figure 12: Numerical mode shapes obtained for model A, B and C.

In order to identify which model better simulated the real behavior of the structure, the numerical frequencies and mode shapes were compared with the ones derived from the dynamic identification tests performed by CESI S.p.A [9]. For the first three global modes identified, the comparison between numerical and experimental results was performed in terms of frequency error and modal assurance criterion (MAC). The latter is a statistical indicator that is normally used to compare the mode shapes obtained from analytical or numerical models with the ones identified experimentally [24], and it was calculated according to the following relation [25]: 


$$
M A C_{u, d}=\frac{\left|\sum_{i=1}^{n} \varphi_{i}^{u} \varphi_{i}^{d}\right|^{2}}{\sum_{i=1}^{n}\left(\varphi_{i}^{u}\right)^{2} \sum_{i=1}^{n}\left(\varphi_{i}^{d}\right)^{2}}
$$

where $\varphi^{u}$ and $\varphi^{d}$ are the experimental and numerical mode shape vectors, respectively, and $i$ indicates the $i$-th degree of freedom, with $i=1 \ldots n, n$ being the total number of degrees of freedom for all the excitation locations. The MAC value ranges from 0 to 1 , where 0 and 1 mean no consistency and full consistency between the modes, respectively.

Table 5 reports the comparison between the numerical and experimental results in terms of frequencies and MAC values for the three models. A similar frequency error of about $60 \%$, calculated on average among the frequencies of the three modes, was obtained for the models. As for the average of MAC values, the MAC obtained for model C (0.53) was much lower than the ones obtained for model A (0.68) and model B (0.69). Since the average frequency error was slightly lower for model B (58.5\%) when compared with model A $(59.8 \%)$, model B was adopted to perform further structural analyses.

\begin{tabular}{cccccccccccc}
\hline & $\begin{array}{c}\text { Experimental } \\
\text { Mode }\end{array}$ & $\begin{array}{c}\text { Frequency } \\
(\mathrm{Hz})\end{array}$ & $\begin{array}{c}\text { Frequency } \\
(\mathrm{Hz})\end{array}$ & $\begin{array}{c}\text { F. Error } \\
(\%)\end{array}$ & $\begin{array}{c}\text { MAC } \\
(-)\end{array}$ & $\begin{array}{c}\text { Frequency } \\
(\mathrm{Hz})\end{array}$ & $\begin{array}{c}\text { F. Error } \\
(\%)\end{array}$ & $\begin{array}{c}\text { MAC } \\
(-)\end{array}$ & $\begin{array}{c}\text { Frequency } \\
(\mathrm{Hz})\end{array}$ & $\begin{array}{c}\text { F. Error } \\
(\%)\end{array}$ & $\begin{array}{c}\text { MAC } \\
(-)\end{array}$ \\
1 & 3.18 & 5.63 & 77.2 & 0.67 & 5.57 & 75.6 & 0.72 & 5.51 & 73.6 & 0.63 \\
2 & 3.76 & 5.78 & 54.0 & 0.81 & 5.77 & 53.6 & 0.77 & 5.70 & 51.7 & 0.34 \\
3 & 4.05 & 6.00 & 48.2 & 0.55 & 5.92 & 46.3 & 0.57 & 5.80 & 43.2 & 0.61 \\
Average all modes & & $\mathbf{5 9 . 8}$ & $\mathbf{0 . 6 8}$ & & $\mathbf{5 8 . 5}$ & $\mathbf{0 . 6 9}$ & & $\mathbf{5 6 . 2}$ & $\mathbf{0 . 5 3}$ \\
\hline
\end{tabular}

Table 5: Comparison between the frequencies and mode shapes obtained numerically (for models A, B and C) and experimentally.

Since the average error between the experimental frequencies and the ones obtained numerically for model B was significant, model updating was necessary to obtain a proper matching between the modal parameters identified numerically and experimentally. Two different strategies of model updating were adopted assuming first the properties of masonry materials and diaphragms and then the stiffness of the soil as the variables to tune. An iterative procedure was used in order to minimize frequency error and MAC. The effect of the efficiency of the connections between orthogonal walls and between walls and slabs on the modal response of the building was not investigated since in both cases an adequate connection was observed, as described in [11].

The first calibration was performed adjusting alternately the properties of masonry materials and diaphragms. As for slabs and roof, the axial stiffness was varied while keeping the bending stiffness constant. However, this strategy was disregarded since considerable reductions of the axial stiffness produced a slight decrease of the numerical frequencies and a sharp reduction of the average MAC. Regarding masonry materials, the elasticity modulus of stone and brick masonry was considered for the updating process. Since the natural frequencies obtained numerically were significantly higher than the experimental ones, a sharp reduction of the reference values initially adopted for the elasticity modulus (reported in Table 2 ) was needed to reach a reasonable average frequency error of about $6 \%$. The latter was obtained considering an elasticity modulus of $700 \mathrm{MPa}, 1050 \mathrm{MPa}$ and $905 \mathrm{MPa}$ respectively for stone masonry, stone masonry with injections and brick masonry.

Table 6 shows the comparison between experimental and numerical results in terms of natural frequencies, relative error and MAC for the updated values of the elasticity modulus of masonry materials. Although these values were still within the range provided by the Italian Circolare [20], such a significant reduction may indicate that masonry was poorly built or it was damaged when the dynamic tests were performed. Alternatively, soil conditions may significantly influence frequency values.

The second calibration was carried out considering soil-structure interaction and adopting a finite stiffness for the soil. In this case, the original values of material properties were used. To model the soil, interface elements (T18IF [19]) were placed at the base of the walls in the numerical model. The values of the normal stiffness modulus $k_{n}$ and shear stiffness modulus $\mathrm{k}_{\mathrm{t}}$ of the interfaces were adopted as the variable to update. On the basis of the values of dynamic Young's modulus and 
dynamic shear modulus of the soil (as reported in [7]), the reference values of the normal stiffness modulus and shear stiffness modulus of the interfaces were assumed as $1.91 \mathrm{E}+05 \mathrm{kN} / \mathrm{m}^{3}$ and $6.83 \mathrm{E}+04 \mathrm{kN} / \mathrm{m}^{3}$, respectively.

\begin{tabular}{ccccccc}
\hline Mode & $\begin{array}{c}\mathrm{f}_{\text {experimental }} \\
(\mathrm{Hz})\end{array}$ & $\begin{array}{c}\mathrm{f}_{\text {numerical }} \\
(\mathrm{Hz})\end{array}$ & $\begin{array}{c}\text { Error } \\
(\%)\end{array}$ & $\begin{array}{c}\text { Average error } \\
(\%)\end{array}$ & $\begin{array}{c}\text { MAC } \\
(-)\end{array}$ & $\begin{array}{c}\text { Average MAC } \\
(-)\end{array}$ \\
1 & 3.18 & 3.60 & 13.5 & & 0.73 & \\
2 & 3.76 & 3.71 & -1.3 & 6.1 & 0.79 & 0.72 \\
3 & 4.05 & 3.91 & -3.5 & & 0.63 & \\
\hline
\end{tabular}

Table 6: Comparison between numerical and experimental frequencies $\mathrm{f}$ and mode shapes for the updated values of the elasticity modulus of masonry materials.

A new eigenvalue analysis was performed on the numerical model with interfaces at the base. Model updating was then carried out adjusting the values of normal and shear stiffness moduli of the interfaces until achieving an error between experimental and numerical frequencies lower than $5 \%$ for both each mode and on average. Such an error was obtained adopting the values of $1.32 \mathrm{E}+05 \mathrm{kN} / \mathrm{m}^{3}$ and $4.71 \mathrm{E}+04 \mathrm{kN} / \mathrm{m}^{3}$ for the normal and shear stiffness moduli, respectively. Note that these values were reasonable for the type of soil present under the building. The comparison between experimental and numerical results in terms of natural frequencies, relative error and MAC for the updated values of stiffness of the interfaces is presented in Table 7.

\begin{tabular}{ccccccc}
\hline Mode & $\begin{array}{c}\mathrm{f}_{\text {experimental }} \\
(\mathrm{Hz})\end{array}$ & $\begin{array}{c}\mathrm{f}_{\text {numerical }} \\
(\mathrm{Hz})\end{array}$ & $\begin{array}{c}\text { Error } \\
(\%)\end{array}$ & $\begin{array}{c}\text { Average error } \\
(\%)\end{array}$ & $\begin{array}{c}\text { MAC } \\
(-)\end{array}$ & $\begin{array}{c}\text { Average MAC } \\
(-)\end{array}$ \\
1 & 3.18 & 3.31 & 4.3 & & 0.89 & \\
2 & 3.76 & 3.65 & -2.8 & 3.1 & 0.55 & 0.72 \\
3 & 4.05 & 3.97 & -2.0 & & 0.71 & \\
\hline
\end{tabular}

Table 7: Comparison between numerical and experimental frequencies $f$ and mode shapes for the updated values of stiffness of the interfaces.

In conclusion, according to the results reported in Table 6 and Table 7 for the two calibrations carried out, the average of MAC values was almost insensitive to the employed updating strategy, whereas the model updating based on the stiffness adopted for the interfaces resulted in a better matching between the natural frequencies obtained experimentally and numerically. Not only was the error, on average, almost the half of the one obtained by updating the elasticity modulus of masonry, but the error in the frequency of the first mode also came down to a value of $4.3 \%$, which was significantly lower that the value of $13.5 \%$ reached with the first calibration. Consequently, the calibrated FE model with interfaces was chosen to perform further structural analyses. For this model, Figure 13 presents the three global mode shapes obtained numerically and corresponding to the experimental ones.

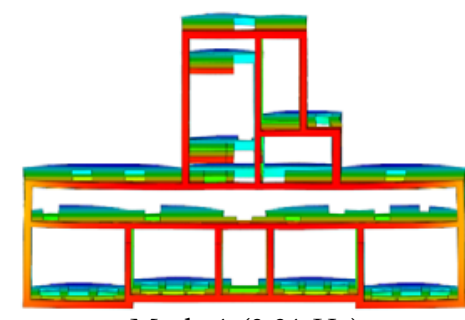

Mode $1(3.31 \mathrm{~Hz})$

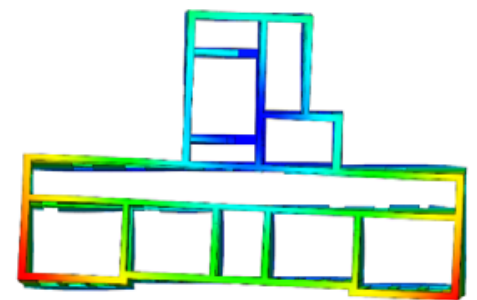

Mode $2(3.65 \mathrm{~Hz})$

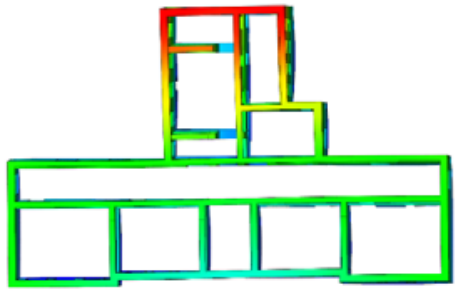

Mode $3(3.97 \mathrm{~Hz})$

Figure 13: Mode shapes of the three global modes obtained for the calibrated model with interfaces (deformation scaling factor equal to 5 for mode 1). 


\section{NONLINEAR STATIC ANALYSES}

$\mathrm{P}$

ushover analyses were performed to evaluate the seismic performance. A regular Newton-Raphson iteration method in combination with an arc-length control and a line search algorithm was used [19]. Note that the arc-length control constrains the norm of the incremental displacements to a prescribed value and simultaneously adapts the size of the increment [19]. Furthermore, when dealing with highly nonlinear problems, the line search method can help the iteration process increasing the convergence rate [19]. A convergence criterion based on energy control with a tolerance value of 0.001 was adopted. A lateral force distribution proportional to the mass of the structure was used to apply horizontal loads. Seismic forces were increased monotonically after the application of the self-weight. The analyses were performed along the $\mathrm{X}$ and $\mathrm{Y}$ global axes of the numerical model, corresponding respectively to the longitudinal and transversal directions of the structure, in both positive and negative directions (Figure 14). As illustrated in Figure 14, a total of eight nodes, which were located at the top of the building and experienced large displacements but small local deformations, were adopted as control points in the analyses. The seismic performance of the structure was assessed in terms of capacity curves and failure mechanisms. Capacity curves were obtained plotting the horizontal load factor (ordinate) against the average of the displacements of the control nodes (abscissa). The horizontal load factor is the ratio between the total force acting horizontally and the total force acting vertically, the latter one corresponding to the self-weight. Damage mechanisms were investigated by plotting the obtained distributions of principal crack width, which is the principal strain for tensile cracking [26].
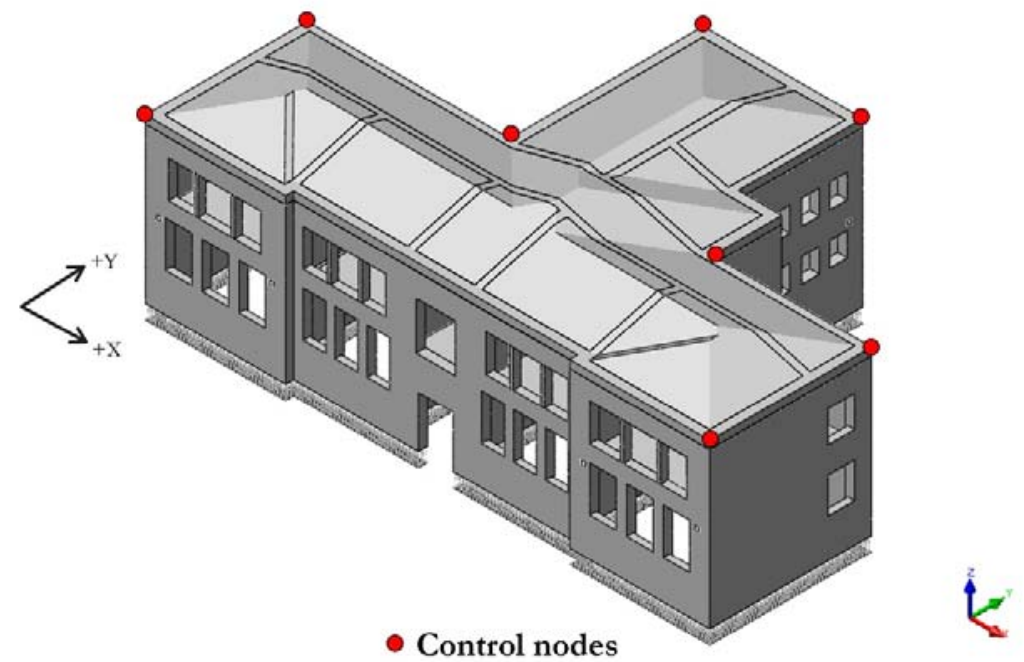

Figure 14: Directions and control nodes for the pushover analyses.

The capacity curves obtained from the pushover analyses in $\pm X$ and $\pm Y$ directions are presented in Figure 15 . For both $X$ and $\mathrm{Y}$ directions, a similar response is observed when the seismic load is applied in the positive or negative direction. In general, the maximum values of applied horizontal load are obtained in $-\mathrm{X}$ and $-\mathrm{Y}$ directions when compared to $+\mathrm{X}$ and $+\mathrm{Y}$ directions. A higher stiffness and lateral load-carrying capacity is obtained in the $\mathrm{X}$ direction when compared to the $\mathrm{Y}$ direction. These results were expected since load-bearing walls developed without interruption along the longitudinal direction $(\mathrm{X})$ of the structure, while there was no continuity in the walls oriented in the transversal direction $(\mathrm{Y})$. In particular, a maximum load factor of about $55 \%$ of the self-weight $(0.55 \mathrm{~g})$ is reached in the -X direction, while a maximum lateral load-carrying capacity of $0.44 \mathrm{~g}$ is obtained in the $-\mathrm{Y}$ direction.

With the aim to compare the damage obtained from numerical analyses with the real crack pattern caused by the AmatriceNorcia-Visso seismic sequence, the damage assessment was performed for values of applied horizontal load comparable to the PGA values recorded in the seismic events of August and October 2016. In particular, reference was made to the two earthquakes that occurred on August 24th $($ PGAx $=0.33 \mathrm{~g}$; PGAy $=0.32 \mathrm{~g})$ and October 26 ${ }^{\text {th }}, 2016$ (PGAx $=0.36 \mathrm{~g}$; PGAy $=0.47 \mathrm{~g})$ (Figure 15). The seismic events of October $26^{\text {th }}\left(\mathrm{M}_{\mathrm{w}}=5.4\right)$ and October $30^{\text {th }}$ were not considered since they did not cause any relevant damage to the structure. It is important to point out that no damage accumulation due to the series of earthquakes can be accounted for in the adopted numerical approach. A similar strategy was used in [27] for the seismic assessment of an historical masonry building that suffered a progressive damage due to a prolonged seismic sequence. 


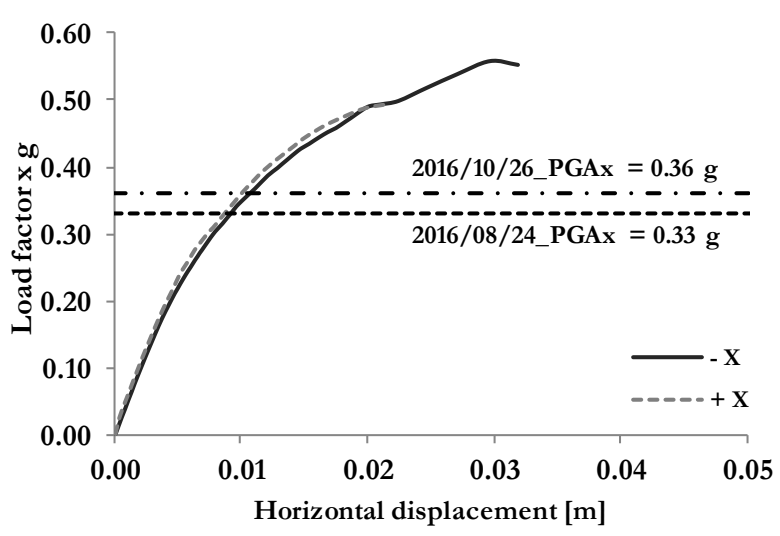

a)

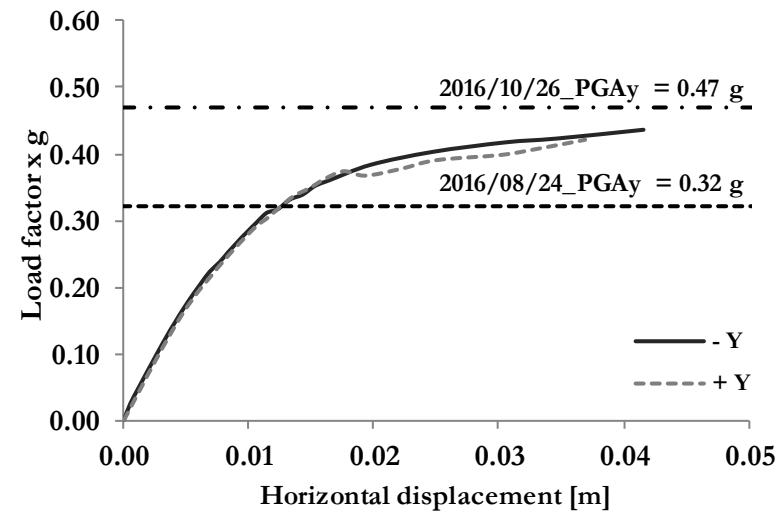

b)

Figure 15: Capacity curves: a) directions $+\mathrm{X}$ and $-\mathrm{X}, \mathrm{b})$ directions $+\mathrm{Y}$ and $-\mathrm{Y}$.

For the $\mathrm{X}$ and $\mathrm{Y}$ directions of analysis, respectively, Figure 16 and Figure 17 present the damage patterns in terms of principal crack width obtained for values of horizontal load factor comparable to the PGA values recorded on August $24^{\text {th }}$, 2016 and October $2^{\text {th }}, 2016$ (see Table 1). Decreasing values of principal crack width are shown in colors ranging from red to white. For each color, the numbers in black in the color legend indicate the boundary values of the corresponding range of principal crack width, while the number in red represent the percentage of mesh elements falling within that range of values. Damage distribution is presented only for the masonry envelope since a linear elastic behavior was assumed for the other structural elements, namely diaphragms, reinforced concrete beams and tie-rods.

For both earthquakes, a global in-plane damage mechanism is observed for all the directions of analysis $( \pm \mathrm{X}$ and $\pm \mathrm{Y})$. It is also noted that the damage mainly consists of diagonal shear cracks occurring in both external and internal walls, in agreement with the damage observed in-situ. It is to highlight that the global failure mechanism predicted by the pushover analysis is consistent with the modal response of the structure. Indeed, the first three modes of vibration identified both experimentally and numerically were global modes with no occurrence of local mechanisms. As for the out-of-plane mechanism induced in one corner of the building by the seismic event of October 26 $6^{\text {th }}, 2016$, it is to note that such a mechanism was difficult to obtain from the numerical model due to the presence of the elastic concrete bond beam at the top of the structure. Furthermore, it possibly resulted from a local disintegration of the material, which was not considered in the FE model.

Regarding the pushover analyses in the direction of the $\mathrm{X}$ global axis, the damage obtained for the seismic event of August $24^{\text {th }}$ (Figure 16a-c) is similar in terms of extent and severity to the one induced by the October $26^{\text {th }}$ earthquake (Figure 16bd). Indeed, both shakes produce a slight damage consisting in the formation of minor cracks, mainly due to in-plane shear stresses, around the openings of body A and body B (Figure 16). A slight increase in the level of damage from August $24^{\text {th }}$ to October $26^{\text {th }}$ can be observed on the basis of the values of principal crack width obtained for the two seismic events considered (Figure 16). Regarding the analysis in the $+\mathrm{X}$ direction, the maximum principal crack width increases from the value of $1.52 \mathrm{~mm}$, obtained for a horizontal load of $0.33 \mathrm{~g}$ (August 24th earthquake), to the value of $1.76 \mathrm{~mm}$, reached under a horizontal load of $0.36 \mathrm{~g}$ (representing the October $26^{\text {th }}$ earthquake). Similarly, when the horizontal load is applied in the -X direction, maximum principal crack widths of $1.58 \mathrm{~mm}$ and $1.93 \mathrm{~mm}$ are obtained for load factors of $0.33 \mathrm{~g}$ (August 24th) and $0.37 \mathrm{~g}$ (October $26^{\text {th }}$ ), respectively. These results were expected since similar PGA values were registered in the X direction of the building in the seismic events of August $24^{\text {th }}$ and October $26^{\text {th }}$. Furthermore, similar average displacements are obtained at the top of the model for either earthquake, as shown in Figure 15. The average top displacement is $9 \mathrm{~mm}$ for the August 24th earthquake, in both $+X$ and $-X$ directions, and is equal to $10 \mathrm{~mm}$ and $11 \mathrm{~mm}$ in the positive and negative direction of analysis, respectively, for the October $26^{\text {th }}$ earthquake.

Figure 18 and Figure 19 show a correlation between the numerical and real damage occurred in some walls oriented in the $\mathrm{X}$ direction for the August 24th and October $26^{\text {th }}$ earthquakes, respectively. It is observed that the damage obtained from pushover analyses is compatible with the crack pattern observed in-situ. In fact, slight to moderate damage is observed for both the seismic events of August 24th (Figure 18) and October 26th (Figure 19). As shown in Figure 18b and Figure 19b-d, the crack width plot depicts a damage pattern mainly consisting in shear cracks present around the openings, in agreement with the real damage experienced by the structure. 
August 24 ${ }^{\text {th }}, 2016($ PGAx $=0.33 \mathrm{~g})$

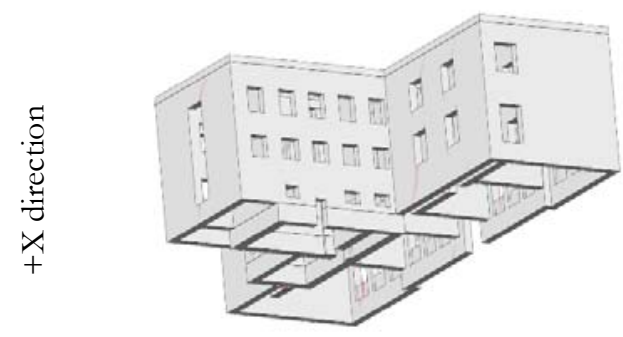

Load factor $0.33 \mathrm{~g}$ - Max. principal crack width $1.52 \mathrm{~mm}$ a)

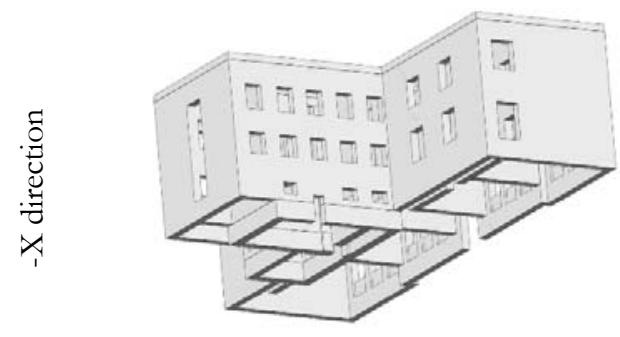

Load factor $0.33 \mathrm{~g}$ - Max. principal crack width $1.58 \mathrm{~mm}$ c)
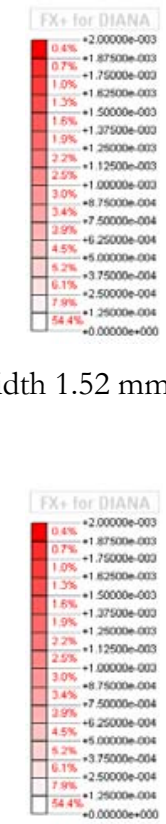
) incipal crack width $1.58 \mathrm{~mm}$
October 26 $6^{\text {th }}, 2016($ PGAx $=0.36 \mathrm{~g})$
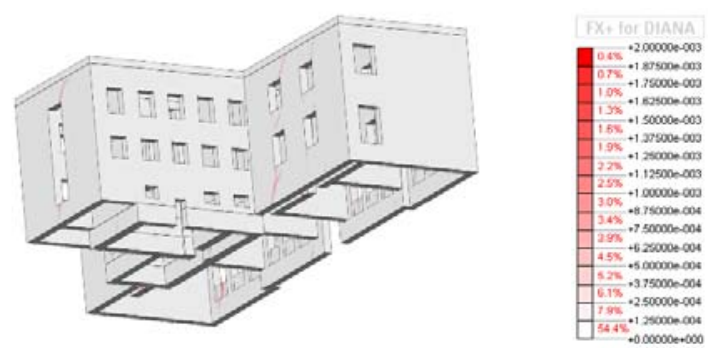

Load factor $0.36 \mathrm{~g}$ - Max. principal crack width $1.76 \mathrm{~mm}$ b)
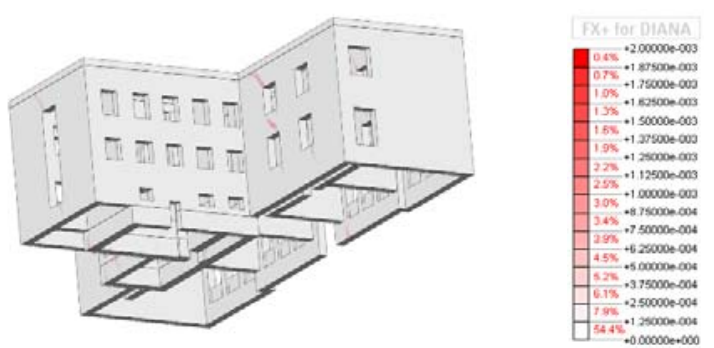

Load factor $0.37 \mathrm{~g}$ - Max. principal crack width $1.93 \mathrm{~mm}$ d)

Figure 16: Principal crack width for horizontal load factors comparable to the PGA recorded in the X direction of the building in the seismic events of August 24 ${ }^{\text {th }}, 2016$ (left) and October 26 ${ }^{\text {th }}, 2016$ (right): a)-b) $+X$ direction, c)-d) -X direction.

August 24 $4^{\text {th }}, 2016($ PGAy $=0.32 \mathrm{~g})$

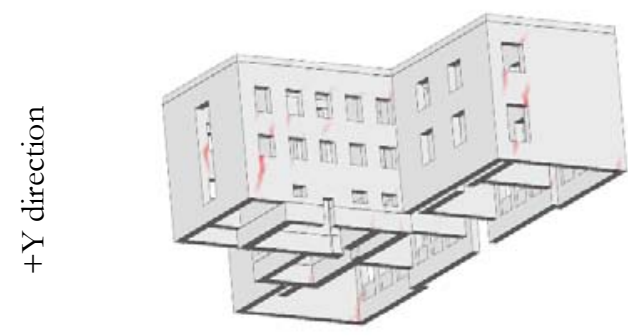

Load factor $0.32 \mathrm{~g}$ - Max. principal crack width $2.07 \mathrm{~mm}$ a)
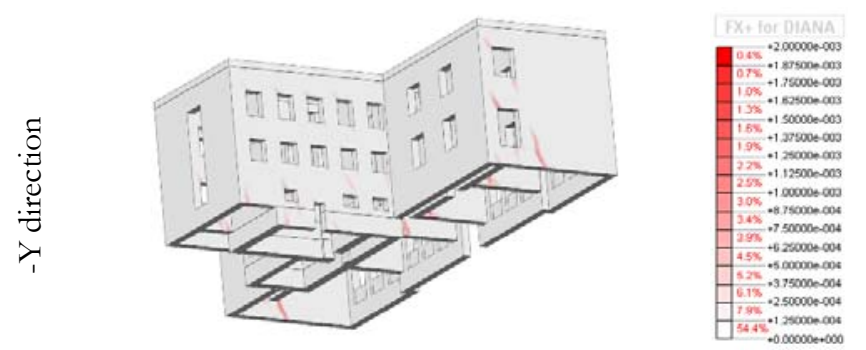

Load factor $0.32 \mathrm{~g}$ - Max. principal crack width $1.70 \mathrm{~mm}$ c)

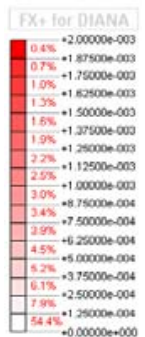

Load factor $0.42 \mathrm{~g}$ - Max. principal crack width $8.51 \mathrm{~mm}$

b)

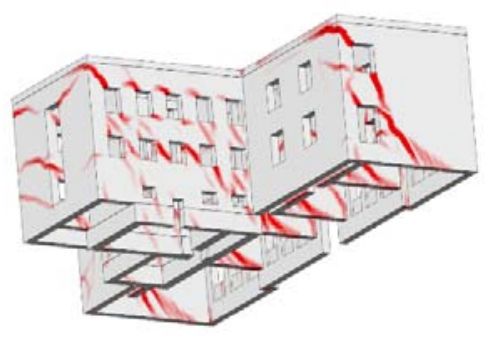

Load factor $0.44 \mathrm{~g}$ - Max. principal crack width $7.29 \mathrm{~mm}$ d)

Figure 17: Principal crack width for horizontal load factors comparable to the PGA recorded in the Y direction of the building in the seismic events of August 24th, 2016 (left) and October 26 $6^{\text {th }}, 2016$ (right): a)-b) +Y direction, c)-d) -Y direction. 


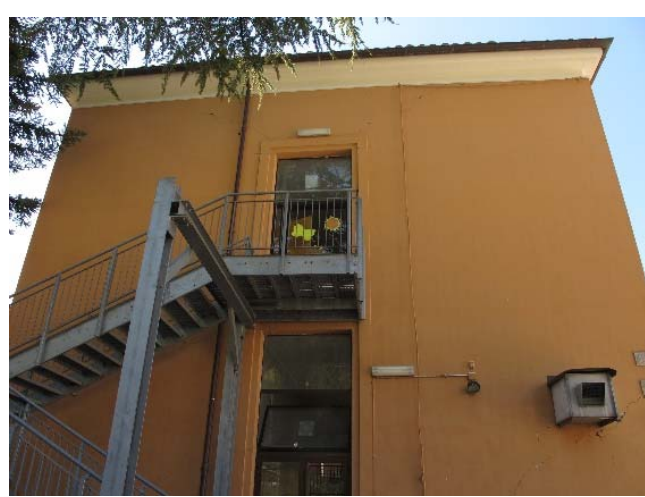

a)

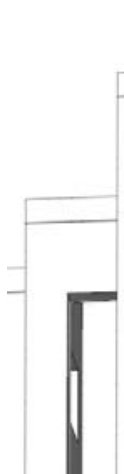

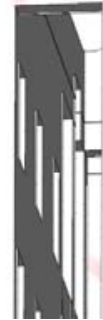

b)
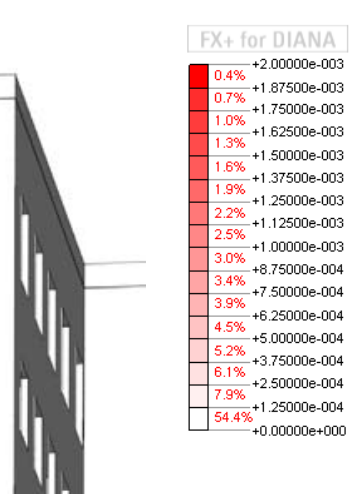

Figure 18: Correlation between the real and numerical damage occurred in the north wall of body B due to the August $24^{\text {th }}$ earthquake $($ PGAx $=0.33 \mathrm{~g}): \mathrm{a})$ cracks observed in-situ [11, 12], b) crack pattern in terms of principal crack width for a horizontal load of $0.33 \mathrm{~g}$ in the $-\mathrm{X}$ direction.

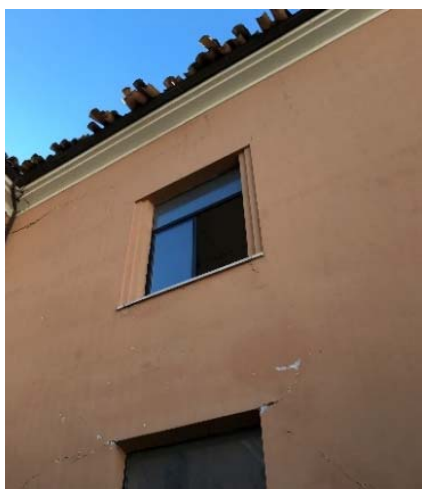

a)

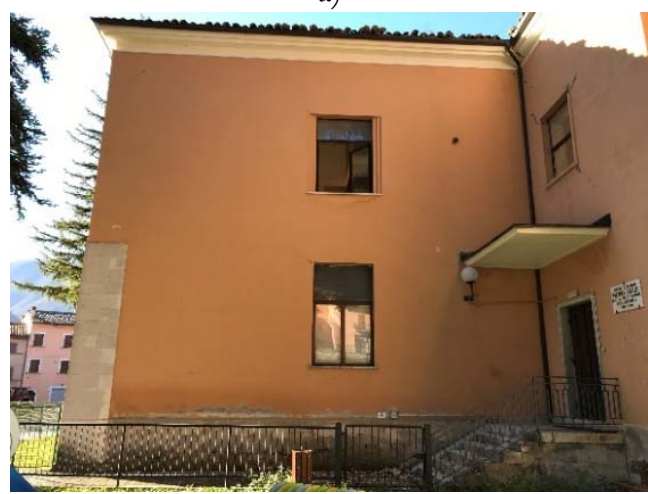

c)
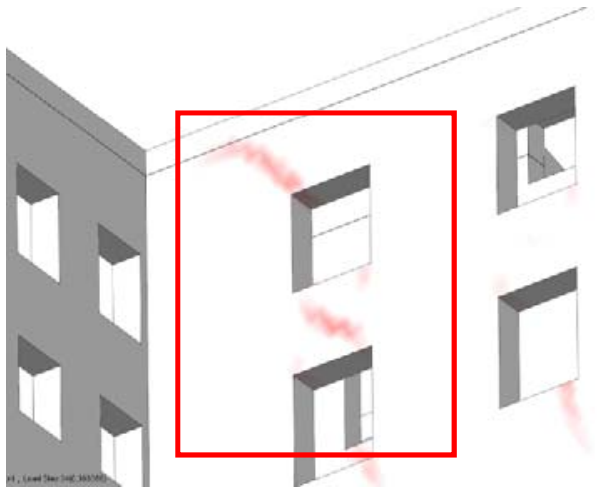

b)
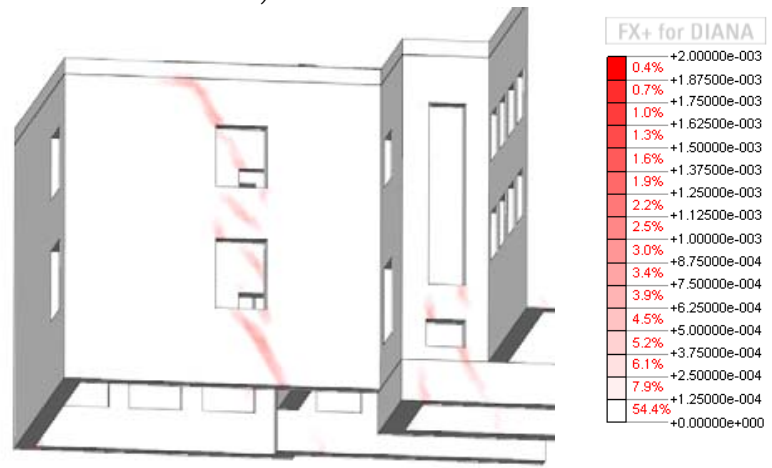

d)

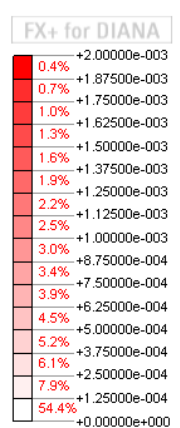

$+0.00000 \mathrm{e}+000$

Figure 19: Correlation between the real and numerical damage occurred in the north external walls of body A due to the October $26^{\text {th }}$ earthquake (PGAx = $0.36 \mathrm{~g})$ : $\mathrm{a}-\mathrm{b})$ cracks observed in-situ [11,12], b-d) crack pattern in terms of principal crack width for a horizontal load of $0.37 \mathrm{~g}$ in $-\mathrm{X}$ direction.

With respect to the pushover analyses performed in the direction of the Y global axis, a moderate damage is obtained under the lateral load of $0.32 \mathrm{~g}$, representing the PGA of the August $24^{\text {th }}$ earthquake, in both the positive and negative directions. Differently from what observed for the X direction, the severity of the damage increases significantly under horizontal loads comparable to the PGA registered in the Y direction of the building in the October 26 $6^{\text {th }}$ earthquake (Figure 17). This was expected since the PGA of the October $26^{\text {th }}$ earthquake was 1.5 times higher than the one of the August $24^{\text {th }}$ earthquake $(0.32 \mathrm{~g})$. Furthermore, from Figure 15 it can be observed that the structure has just exited the linear elastic range for the PGA of the August $24^{\text {th }}$ earthquake, whereas it shows a highly nonlinear response for the October $26^{\text {th }}$ earthquake. Under a lateral load of $0.32 \mathrm{~g}$ (August $24^{\mathrm{th}}$ ) an average top displacement of about $12 \mathrm{~mm}$ is obtained in both $+\mathrm{Y}$ and $-\mathrm{Y}$ direction, whereas the top displacement increases to about $37 \mathrm{~mm}$ and $42 \mathrm{~mm}$ in the $+Y$ and $-Y$ directions, respectively, for horizontal 
loads of $0.42 \mathrm{~g}$ and $0.44 \mathrm{~g}$ (approximately equal to the PGA of the October 26 $6^{\text {th }}$ earthquake). The deterioration of the building conditions can also be observed from the significant rise of the maximum values of the principal crack width. For the analysis in $+Y$ direction, the latter increases from $2.07 \mathrm{~mm}$ for the August 24th earthquake to $8.51 \mathrm{~mm}$ for the October $26^{\text {th }}$ earthquake. A similar trend is observed in the $-Y$ direction, where values of $1.70 \mathrm{~mm}$ and $7.29 \mathrm{~mm}$ are obtained under horizontal loads comparable to the PGA values of the August $24^{\text {th }}$ and October $26^{\text {th }}$ shakes, respectively.

Figure 20, Figure 21 and Figure 22 present the numerical and real damage caused to some walls oriented in the Y direction by the seismic events of August $24^{\text {th }}$ and October $26^{\text {th }}$. It is observed that the damage patterns obtained from pushover analyses are in good agreement with the damage observed in-situ, this confirming the validity of the numerical model. For the August 24th earthquake, fine and moderate cracks, mainly due to shear, occur in both external (Figure 20c and Figure 21c) and internal walls (Figure 22c). As shown in Figure 20d, Figure 21d and Figure 22d, the earthquake of October $26^{\text {th }}$ produces a significant increase in the level of damage, which consists in the enlargement of the existing cracks and opening of new ones. As a result, severe cracks are observed throughout the building in both the external and internal walls. The damage mechanism mainly consists of diagonal shear cracks developing through the entire thickness of the walls in both piers and spandrels (Figure 20d and Figure 21d). Flexural cracks are also observed around the openings of the external walls, as shown in Figure 20d and Figure 21d.

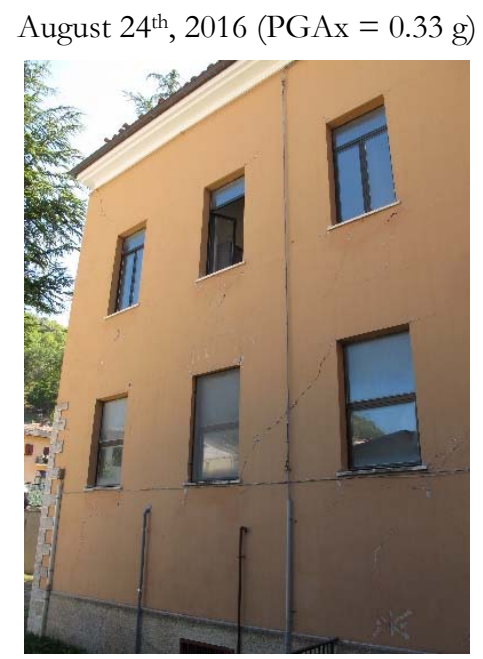

a)

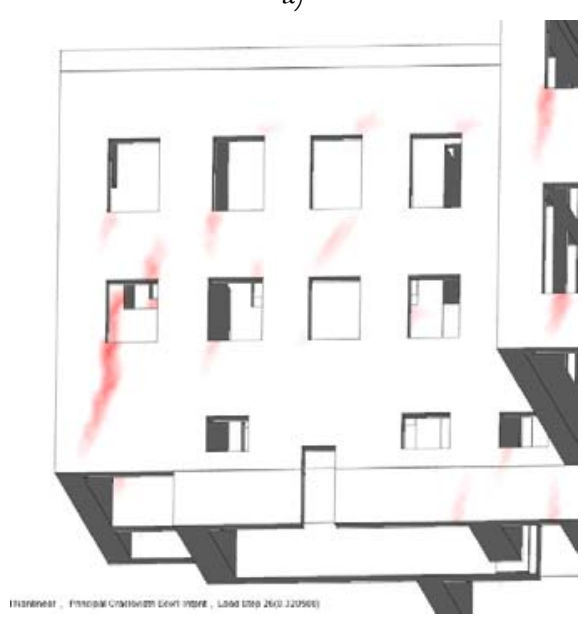

c)

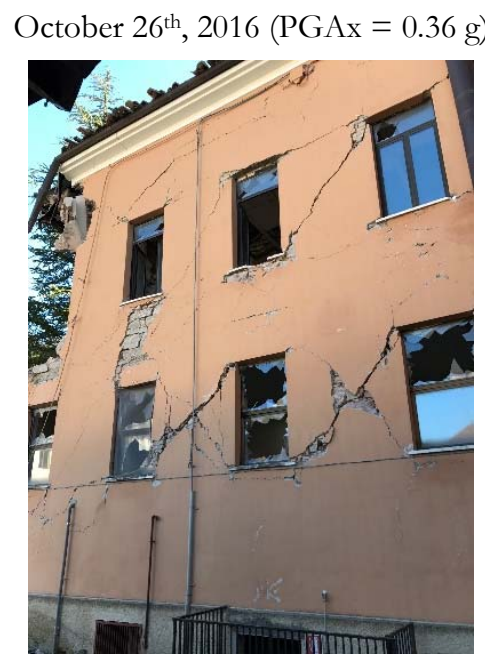

b)

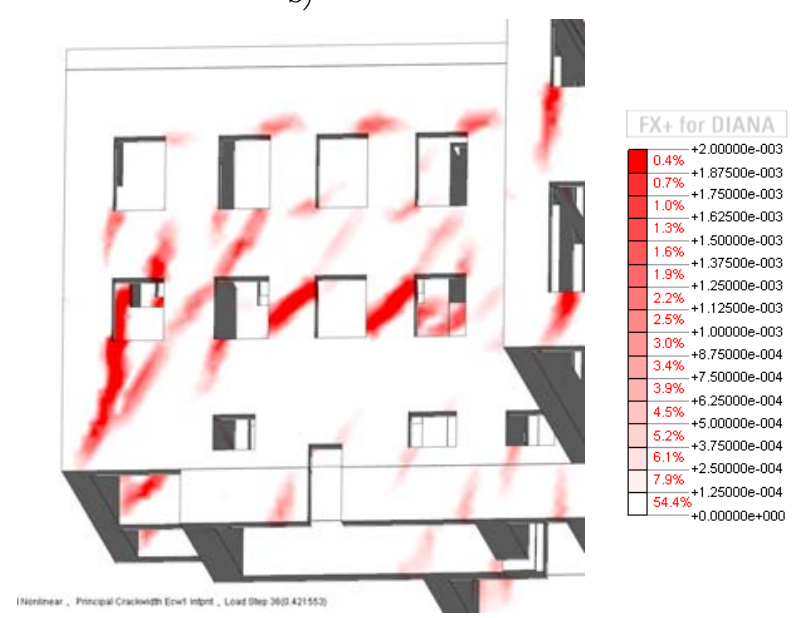

d)

Figure 20: Correlation between the real and numerical damage occurred in the west external wall of body B due to the August $24^{\text {th }}$ (left) and October $26^{\text {th }}$ (right) earthquakes: a-b) cracks observed in-situ [11, 12], c) crack pattern in terms of principal crack width for a horizontal load of $0.32 \mathrm{~g}$ in the $+\mathrm{Y}$ direction, d) crack pattern in terms of principal crack width for a horizontal load of $0.42 \mathrm{~g}$ in the $+\mathrm{Y}$ direction. 


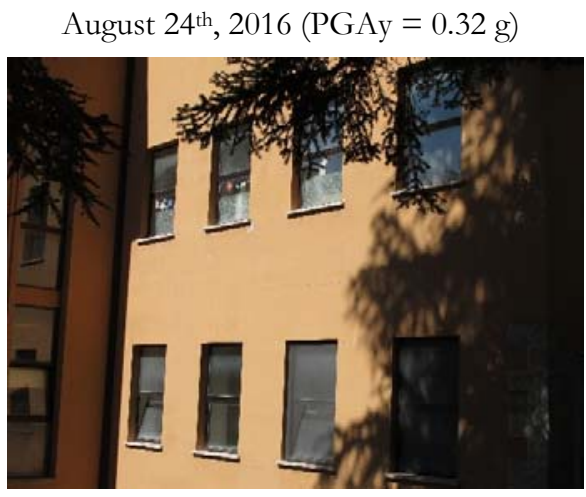

a)

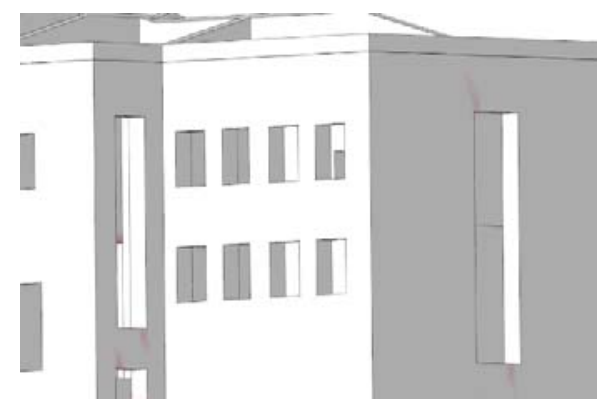

c)
October 26 $6^{\text {th }}, 2016($ PGAy $=0.47 \mathrm{~g})$

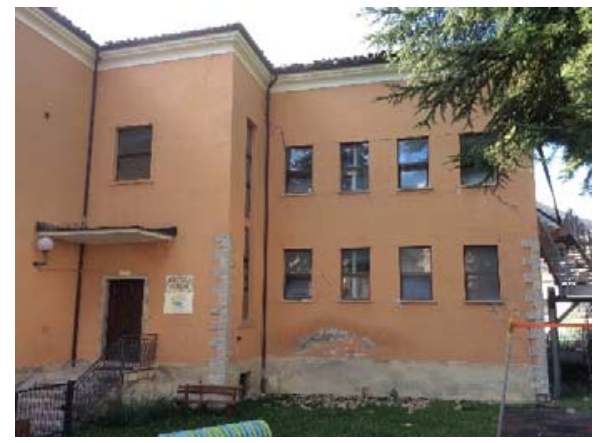

b)

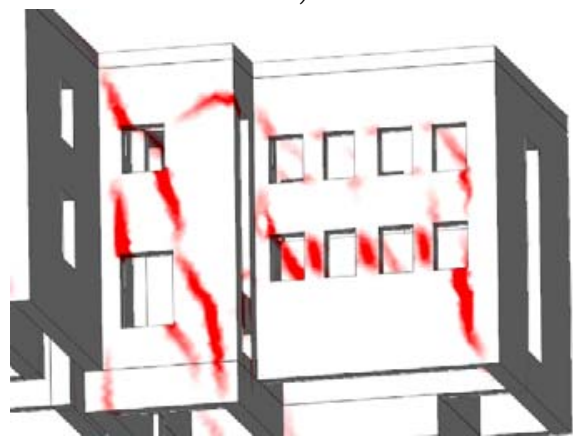

d)

Figure 21: Correlation between the real and numerical damage occurred in the east external wall of body B due to the August 24th (left) and October $26^{\text {th }}$ (right) earthquakes: a-b) cracks observed in-situ [11, 12], c) crack pattern in terms of principal crack width for a horizontal load of $0.32 \mathrm{~g}$ in the $+\mathrm{Y}$ direction, d) crack pattern in terms of principal crack width for a load of $0.42 \mathrm{~g}$ in the $+\mathrm{Y}$ direction.

August 24th $2016($ PGAy $=0.32 \mathrm{~g})$

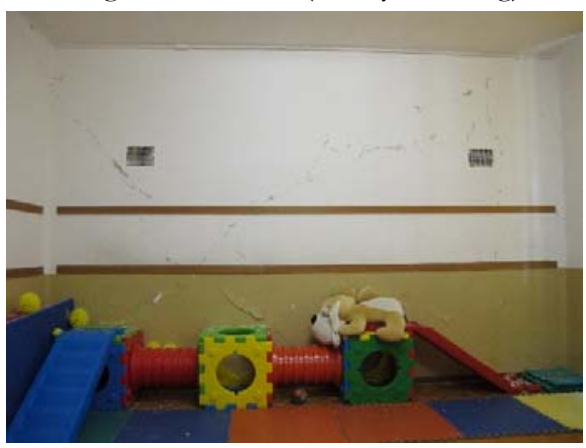

a)

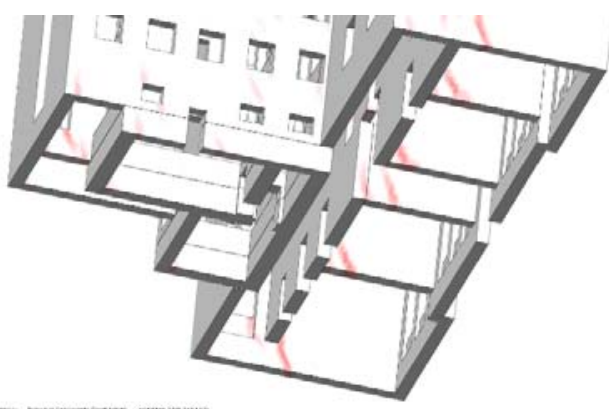

c)

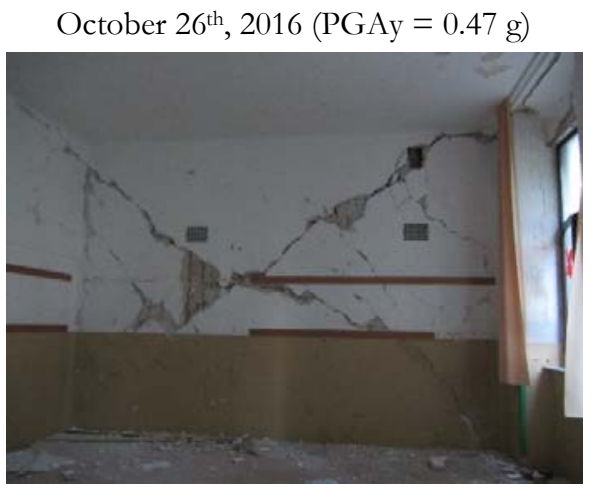

b)

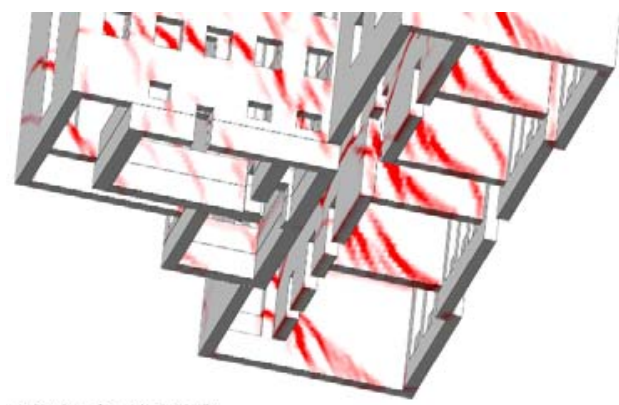

d)

Figure 22: Correlation between the real and numerical damage occurred in the internal walls of body A due to the August $24^{\text {th }}$ (left) and October $26^{\text {th }}$ (right) earthquakes: $\left.a-b\right)$ cracks observed in-situ [11, 12], c) crack pattern in terms of principal crack width for a horizontal load of $0.32 \mathrm{~g}$ in the $-\mathrm{Y}$ direction, $\mathrm{d}$ ) crack pattern in terms of principal crack width for a horizontal load of $0.44 \mathrm{~g}$ in the $-\mathrm{Y}$ direction. 


\section{SUMMARY AND CONCLUSIONS}

$\mathrm{T}$ his paper presented the seismic assessment of "Pietro Capuzi" school, located in Visso, in the Marche region, Italy. The school is an interesting example to assess the capability of advanced numerical methods to realistically simulate the response of existing masonry buildings to horizontal loads.

The school was severely damaged by the seismic sequence that hit the regions of Central Italy between 2016 and 2017. Being part of the Seismic Observatory of Structures, a permanent monitoring system was present in the building and allowed registering both the ground motion and accelerations experienced at the different levels of the structure during the entire seismic sequence. The progressive damage suffered by the building due to the considered series of earthquakes was analyzed in terms of crack pattern and inter-story drift. The structure exhibited a global failure mechanism associated to the in-plane response of load-bearing masonry walls. Slight to moderate damage was induced by the earthquake of August 24th, 2016, which initiated the Amatrice-Norcia-Visso sequence. Subsequently, the severity of the damage increased significantly due to the seismic event of October $26^{\text {th }}, 2016$, which produced severe cracks throughout the building and also activated an outof-plane mechanism. The most significant in-plane damage occurred in the load-bearing walls oriented in the Y direction of the structure, in agreement with both the higher values of PGA and inter-story drift registered in this direction and the higher vulnerability exhibited by the building in the $\mathrm{Y}$ direction compared to the $\mathrm{X}$ direction

In order to simulate the seismic response of the structure by means of numerical methods, a three-dimensional FE model was prepared, adopting a macro-modeling approach to represent masonry. Material properties were defined based on the Italian building code and literature recommendations, considering also the results of past inspections and experimental tests. It is important to highlight that three different models were first created to account for different possible modeling strategies of the partially sub-grade basement. The models were then evaluated in terms of modal parameters (i.e. natural frequencies and mode shapes) comparing the numerical results with those of past dynamic identification tests. The model providing the best compromise between low average frequency error and high MAC was thus identified as the model that better simulated the structural response of the building. A process of model updating was then performed on such model to obtain a good agreement between the modal parameters identified numerically and those obtained experimentally. Two different strategies of model updating were adopted based on either tuning the elasticity modulus of masonry or considering the finite stiffness of the soil by means of interface elements. The latter strategy resulted in a better matching between the numerical and experimental frequencies and mode shapes. Consequently, soil conditions were proved to affect the modal response of the building and the calibrated model with interfaces was used to perform seismic analysis.

Pushover analyses were carried out along the longitudinal $(\mathrm{X})$ and transversal $(\mathrm{Y})$ primary axes of the building, in both positive and negative directions. On the basis of the results obtained in terms of capacity curves, the transversal direction was identified as the most vulnerable direction of the building. Indeed, a lower stiffness and lateral load-carrying capacity were observed in the $\mathrm{Y}$ direction compared to the $\mathrm{X}$ direction, as expected due to the presence of continuous load-bearing walls only in the $\mathrm{X}$ direction. The damage was assessed for values of horizontal load comparable to the PGA values registered in the seismic events of August 24th and October $26^{\text {th }}, 2016$. For either earthquake, a global in-plane response was obtained with diagonal shear cracks occurring in both external and internal walls. Slight to moderate damage was observed in the analyses in the $\mathrm{X}$ direction for both the considered seismic events. Regarding the analyses in the $\mathrm{Y}$ direction, the severity of the existing damage significantly increased for the October $26^{\text {th }}$ earthquake when compared to the August $24^{\text {th }}$. Nevertheless, it is noted that the failure mechanisms did not change for the October $26^{\text {th }}$ earthquake but still consisted in diagonal cracks mainly induced by shear stresses.

Generally, for both the studied seismic events it is noted that the damage obtained in the numerical model resembles the one observed in-situ in terms of severity and failure mechanisms. Regarding the out-of-plane mechanism produced by the October $26^{\text {th }}$ earthquake, it is believed that its occurrence in the numerical model was prevented by the presence of an elastic reinforced concrete bond beam at the top of the building. Furthermore, such a mechanism could have resulted from a possible disintegration of masonry materials, which was not considered in the FE model. Future analyses could be carried out adopting a non-linear behavior for reinforced concrete beams, which could help in obtaining the activation of the outof-plane mechanism. In conclusion, the good agreement between the numerical and real damage provided a validation of the numerical model and the modeling strategies adopted to prepare it.

\section{ACKNOWLEDGEMENTS}

he authors wish to express their gratitude to the Seismic Observatory of Structures, RELUIS and Ing. Serena Cattari of the University of Genova for the material provided for the development of the present work. The work was carried out thanks to the financial support of the European Commission within the framework of the SAHC master 
course. The authors are grateful to the SAHC Consortium and the University of Minho in Guimarães (Portugal) for the support provided.

\section{REFERENCES}

[1] Lourenço, P.B., Mendes, N., Ramos, L.F., Oliveira, D. V. (2011). Analysis of Masonry Structures Without Box Behavior, Int. J. Archit. Herit., 5, pp. 51-59. DOI: 10.1080/15583058.2010.528824

[2] Felice, G. De., Santis, S. De., Lourenço, P.B., Mendes, N. (2017). Methods and Challenges for the Seismic Assessment of Historic Masonry Structures, Int. J. Archit. Herit., 11(1), pp. 143-60. DOI: 10.1080/15583058.2016.1238976

[3] Roca, P., Cervera, M., Gariup, G., Pela', L. (2010). Structural analysis of masonry historical constructions. Classical and advanced approaches, Arch. Comput. Methods Eng., 17(3), pp. 299-325. DOI: 10.1007/s11831-010-9046-1

[4] DPC Osservatorio Sismico delle Strutture (2017). OSS Download Service. Available at: http://www.mot1.it/ossdownload (accessed April 12, 2017).

[5] Cattari S., Degli Abbati S., Ottonelli D., Marano C., Camata G., Spacone E., da Porto F., Modena C., Lorenzoni F., Magenes G., Penna A., Graziotti F., Ceravolo R., Miraglia G., Lenticchia E., Fiorini N., Spina D. (2019). Discussion on data recorded by the Italian structural seismic monitoring network on three masonry structures hit by the 2016-2017 Central Italy earthquake, Proc. of COMPDYN 2019, Crete, 24-26 June 2019.

[6] S.G.M. S.r.l. (2010). Rilievo geometrico e strutturale - Scuola elementare "Pietro Capuzi"- Visso (MC) (in Italian).

[7] S.G.M. S.r.l. (2011). Relazione P4134-20/11 del 16/02/2011 - Rilievo proprietà meccaniche e rilievo geometrico costruttivo - Scuola elementare e materna "Pietro Capuzi" - Visso (MC) (in Italian).

[8] S.G.M. Engineering (2011). Modellazione e analisi numerica - Scuola elementare e materna "P. Capuzi" - Visso (MC) (in Italian).

[9] CESI S.p.A. (2010). Caratteristiche del sistema di monitoraggio sismico - Rapporto di installazione - Scuola materna "P. Capuzi" - Visso (MC) (in Italian).

[10] ISS (2017). Indagini conoscitive e monitoraggi nell'ambito dell'Osservatorio Sismico delle Strutture. Available at: http://www.mot1.it/iss/iss_visualizza_struttura.php?id_struttura=68\&directory=dat (accessed April 12, 2017).

[11] Cattari, S., Degli Abbati, S., Ottonelli, D., Sivori D., Spacone, E., Camata, G., Marano, C., Da Porto, Modena C., F., Lorenzoni, F., Penna, A., Graziotti, F., Ceravolo, R., Matta, E., Miraglia, G., Spina, D., Fiorini, N. (2018). Task 4.1 Workgroup_Report di sintesi sulle attività svolte sugli edifici in muratura monitorati dall'Osservatorio Sismico delle Strutture, Linea Strutture in Muratura, ReLUIS report, Rete dei Laboratori Universitari di Ingegneria Sismica (in Italian).

[12] DPC (2016). Photographic survey performed during Amatrice-Norcia-Visso seismic sequence.

[13] Ferrero C (2017). 2016 Central Italy Earthquake: Seismic Assessment of "Pietro Capuzi" School in Visso (Marche). SAHC master thesis, University of Minho, Guimarães, Portugal.

[14] Structural-Vibration-Solutions (2016). ARTeMIS Modal, 5.0.0.1 user's manual, Denmark.

[15] DPC Osservatorio Sismico delle Strutture (2017). Rapporto OSS.

[16] Seismosoft (2016). SeismoSignal - A computer program for signal processing of time-histories. Available at: http://www.seismosoft.com.

[17] NTC (2008). Decreto Ministeriale 14/01/2008. Ministero delle Infrastrutture e dei Trasporti., G.U. n. 29 of 04/02/2008 (in Italian).

[18] FX+ for DIANA (2013). Midas FX+ for DIANA, Customized Pre/Post-processor for DIANA

[19] TNO DIANA BV (2014), DIANA Finite Element Analysis User's Manual Release 9.6, Delft, The Netherlands.

[20] Circolare esplicativa alle NTC 2008 (2009). Circolare n. 617 of 02/02/2009. Istruzioni per l'applicazione delle nuove norme tecniche per le costruzioni di cui al decreto ministeriale 14 gennaio 2008 (in Italian).

[21] Tomaževič, M. (2009). Shear resistance of masonry walls and Eurocode 6: shear versus tensile strength of masonry, Mater. Struct., 42(7), pp. 889-907. DOI: 10.1617/s11527-008-9430-6

[22] Angelillo, M., Lourenço, P.B., Milani, G. (2014). Masonry behaviour and modelling, In: Angelillo M. (eds) Mechanics of Masonry Structures. CISM International Centre for Mechanical Sciences, Vienna, Springer, 551, pp. 1-26, DOI: 10.1007/978-3-7091-1774-3_1

[23] Lourenço, P.B. (1996). A user/programmer's guide for the micro-modelling of masonry structures. Report 03.21.1.31.35, Delf University of Technology, Delf, The Netherlands - University of Minho, Guimarães, Portugal.

[24] Pastor, M., Binda, M., Harcarik, T. (2012). Modal Assurance Criterion, Procedia Eng., 48, pp. 543-8, DOI: $10.1016 /$ j.proeng.2012.09.551 
[25] Mendes N. (2012). Seismic assessment of ancient masonry buildings: shaking table tests and numerical analysis. PhD thesis, University of Minho, Guimarães, Portugal.

[26] Lourenço, P.B., Trujillo, A., Mendes, N., Ramos, L.F. (2012). Seismic performance of the St. George of the Latins church: Lessons learned from studying masonry ruins, Eng. Struct., 40, pp. 501-518, DOI: 10.1016/j.engstruct.2012.03.003

[27] Silva, L., Mendes, N., Lourenco, P., Ingham, J. (2018). Seismic Structural Assessment of the Christchurch Catholic Basilica, New Zealand, Structures, 15, pp. 115-130, DOI: 10.1016/j.istruc.2018.06.004 